\title{
ユニバーサル多点プレス法による船体外板曲げ 作業の自動化に関寸る研究
}

（第 1 報: 基 礎 的 研 究）

\begin{tabular}{|c|c|c|c|c|c|c|c|c|}
\hline 正員 & 西 & 岡 富 仁 & 雄* & 正員 & 西 & 牧 & & 興** \\
\hline 正員 & 松 & 石 正 & 克** & 正員 & 田 & 中 & & 武*** \\
\hline 正員 & 安 & 川 & 度 $* * * *$ & 正員 & 山 & 内 & 俊 & 雄*** \\
\hline 正員 & 東 & 郷 & 修**** & & & & & \\
\hline
\end{tabular}

On Automatic Bending of Plates by the Universal Press with

Multiple Piston Heads

(1st Report : Fundamental Study)

by Fujio Nishioka, Member

Koh Nishimaki, Member

Masakatsu Matsuishi, Member

Takeshi Tanaka, Member

Wataru Yasukawa, Member

Toshio Yamauchi, Member

Osamu Tohgoh, Member

Summary

To the forming of curved shells of ships, the line heating method is extensively applied. However, the line heating method is not suitable for automatic operation.

The authors investigated a new system of plate bending, which is composed of a universal press with multiple piston heads. The universal press with multiple piston heads is quite suitable for numerically controled operation. Yet, there exist many problems which must be solved before the universal press is in practical use.

In the paper, the authors conducted experimental investigation of plate bending by small press with a solid head (10 ton) and large universal press with multiple piston heads (500 ton). Various informations are obtained on the reproduceability of the results, the fairness of curved plate after bending, the amount of spring back after bending, the effect of pitch of multiple piston heads, etc.

The authors also carried out theoretical investigations into the deformation of plates and proposed valuable empirical formulae.

In the next paper, the authors will discuss the results of investigation into the various problems which arises from the numerically controled operation of the universal press with multiple piston heads.

\footnotetext{
* 日立造船 (株) 船舶事業本部

** 日立造船 (株) 技術研究所

*** 川崎重工業 (株) 神戸工場

**** 川崎重工業(株)技術研究所

***** 石川島播磨重工業(株) 相生工場
} 


\section{1 緒言}

船改構造用鋼板の曲げ加工は，内業工程の中で最も近代化の遅れた分野の 1 つであり，その手法と精度は熟練 作業者の経験と勘に頼りまた多数の作業員を必要としている。そこで設計的配慮を合わせて，板曲げ加工作業 の自動化，NC 化の促進をはかることは，船殼工作のアンマンド化の一環としてきわめて重要であるとともに， 工程管理上飞も大きな意義をもつものと考克られる。

本研究では，このような観点から曲げ加工システムに関する検討を行ったが，第 1 報では NC 化に適した曲げ 加工法としてニニバーサル多点プレス方式を選択し，その実用化に対する具体的な問題点の検討結果を報告す る。すなわち，船体曲面を代表する小形単一曲げ型によるプレス実験およびュニバーサル多点プレス装置の部分 模型による大形実験を行い, 成型結果の再現性, 成型曲面の平滑度, 曲げ加工後のスプリングバック量の大きさ と曲面形状の関係，多点と゚ストンのピッチの成型に及ぼす影響などを検討した。さらに，設定曲面とスプリング バック後の曲面の関係を理論的に求め, 実験結果と比較して実験式を求めた。以上の結果を基にして, ニニバー サル多点プレス方式の実用化の可能性を判断した。

引続き第 2 報では，ニニバーサル多点プレス方式による自動曲げ加工の具体化のための研究結果を述べる。

\section{2 曲げ加工法の選定}

板曲げ方式として一般に考兄られるものには線状加熱方式および機械的曲げ加工方式があり，これらの加工法 の特徵をTable 1 亿示す。このうち，現在造船工業で実施されている線状加熱方式の自動化を考える場合，設備 費が後述するプレス方式に比しかなり安いことが予想され，したがって各造船所ごとに簡単に設置できる可能性 が大きい。しかし，線状加熱の場合は結果に影響を及ぼす因子が極めて多種であり，しかも，それらが相互微

Table 1 曲げ加工方式の比較

\begin{tabular}{|c|c|c|}
\hline & 線状加熱方式 & $\begin{array}{l}\text { 機械的曲げ加 } \\
\text { 工方式 }\end{array}$ \\
\hline 作 業 手 順 & 手作業 (ガス十水) & 機㭜(プレス) \\
\hline 設 備 費 & 少＜wide>額 & 多 \\
\hline 影響因子数 & 多 & 少 \\
\hline 影 響 因 子 & $\begin{array}{l}\text { 加 熱 温 度 } \\
\text { 加 熱 順 序 } \\
\text { 冷 却 方 式 } \\
\text { 冷 却 速 度 } \\
\text { 鋼板支持条件 }\end{array}$ & プレス型の形状 \\
\hline 理 論 解 析 & 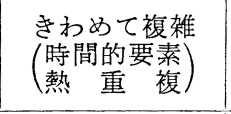 & 比較的簡単 \\
\hline 自動化の難易 & 困 & 比較的容易 \\
\hline 考案 事 項 & & $\begin{array}{l}\text { ニニバーサル } \\
\text { 多点プレス }\end{array}$ \\
\hline
\end{tabular}

妙な影響を及湆し合らため，その加工条件の制御は極 めて困難で精度の高い曲げ加工は期待できない。

一方，プレスによる曲げ加工法を自動化する場合の 長所は，加工方法の決定が押型の設定の及ですむ点に ある。しかし，押型をあらゆる船体曲面住対して準備 する事は不可能であり，これを解決するためにはニニ パーサル多点プレス方式の採用が良いと考兄られる。 ニニバーサル多点プレスでは，上型怙よび下型沉相当 する位置に多数のピストン（ピストンヘッドはボール ジョイントでニニバーサルに回転可能）を配置し，こ のピストンヘッド群の高さを所要の曲げ形状に対応し て設定して、これをプレス型として曲げ加工を行うも のである。また自動化のための制御方式もユニバーサ ル多点プレス方式は, 線状加熱方式に比較して容易で あると考兄られる。

したがって，本研究ではニニバーサル多点プレス方 式をとりあげることにした。

\section{3 船体外板曲面形状の傾向調査}

外板の曲げ加工の自動化の研究を行うに先立って, 実船に括ける外板の形状, 曲率等の概要を把握しておく事 は問題点の摘出, 装置規模の推定等のために必要である。そこで見在建造されている船型のうち, 代表的なるの としてタンカー, ばら積み船扣よび貨物船各 1 隻を選び, それぞれについて曲り外板の形状, 絽横曲率, 数量を 調査した。調査対象船の要目拉よび調査数量をTable 2 および Table 3 に示す。

曲り形状の求め方は Fig. 1 に示すように板幅沶よび板長さのほぼ中央でそれぞれ弦長 $(2 l, 2 b)$ 拈よび弧高さ

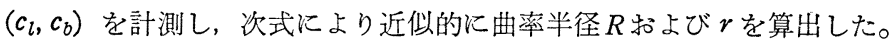

$$
\frac{1}{R}=\frac{2 c_{l}}{l^{2}+c_{l}^{2}}, \quad \frac{1}{r}=\frac{2 c_{b}}{b^{2}+c_{b}^{2}}
$$


Table 2 調 查 対 象 船

\begin{tabular}{|c|c|c|c|c|c|c|c|}
\hline \multirow[b]{2}{*}{ 船 } & \multirow{2}{*}{\multicolumn{2}{|c|}{ 種 }} & \multicolumn{3}{|c|}{ 要 } & \multicolumn{2}{|l|}{ 目 } \\
\hline & & & $\begin{array}{l}\text { D. W. } \\
\text { (ton) }\end{array}$ & $\begin{array}{l}L_{P P} \\
(\mathrm{~m})\end{array}$ & $\begin{array}{c}B \\
(\mathrm{~m})\end{array}$ & $\begin{array}{c}D \\
(\mathrm{~m})\end{array}$ & $C_{b}$ \\
\hline 夕 & ン & - & 210,000 & 289.0 & 50.8 & 25.7 & 0.814 \\
\hline :ே2 & ら 積 & 船 & 120,000 & 250.0 & 42.0 & 22.8 & 0.817 \\
\hline 保 & 物 & 船 & 12,700 & 147.0 & 22.4 & 13. 7 & 0.553 \\
\hline
\end{tabular}

Table 3 曲り 外板 形状調查数量

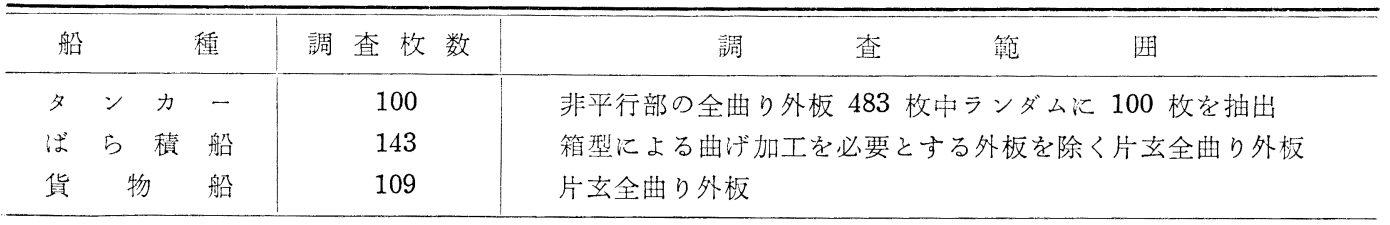

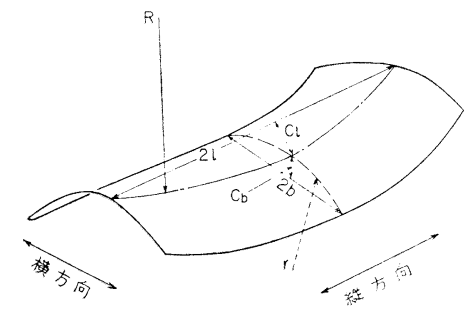

Fig. 1 曲率 半径

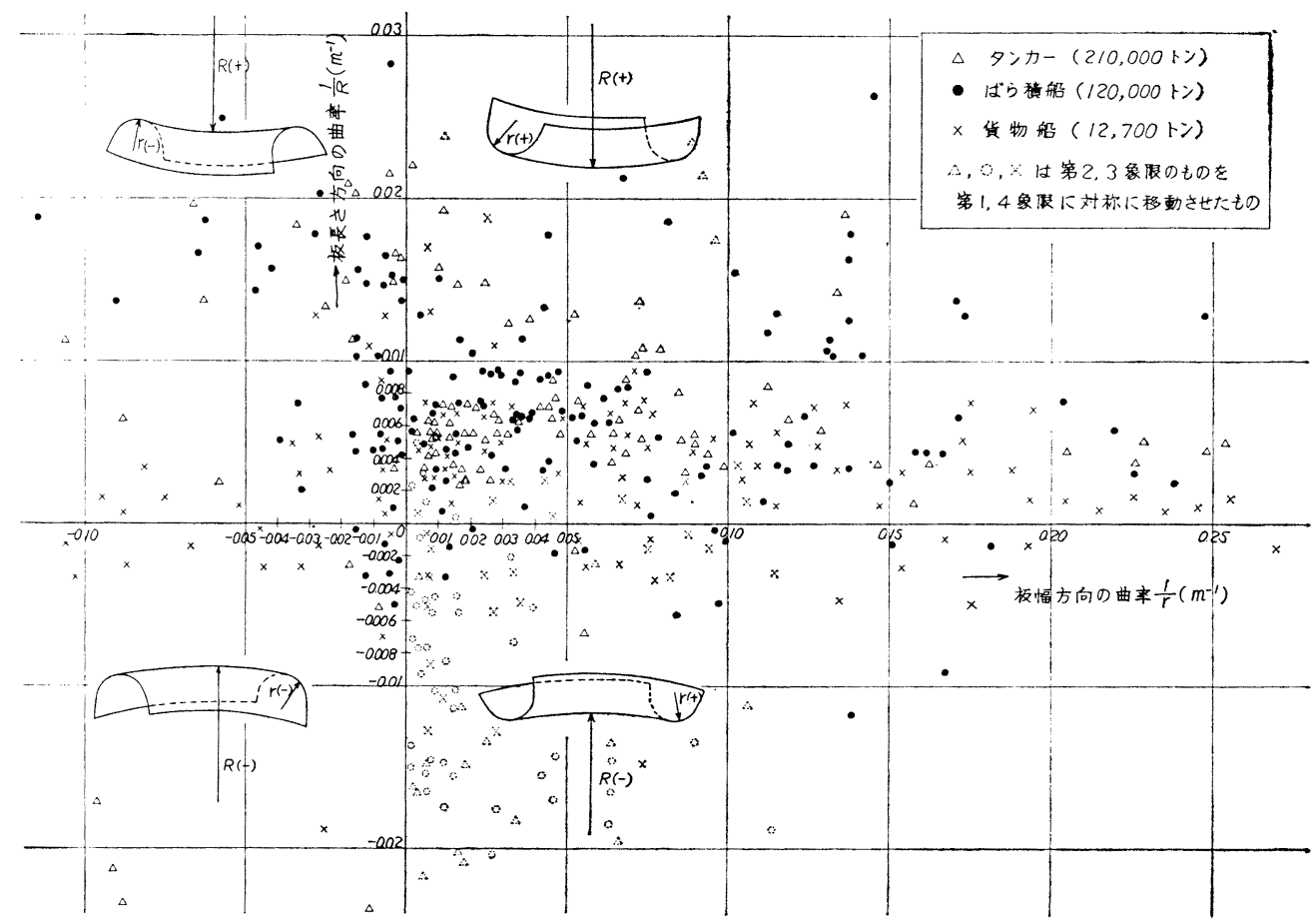

Fig. 2 外板曲率分布図 


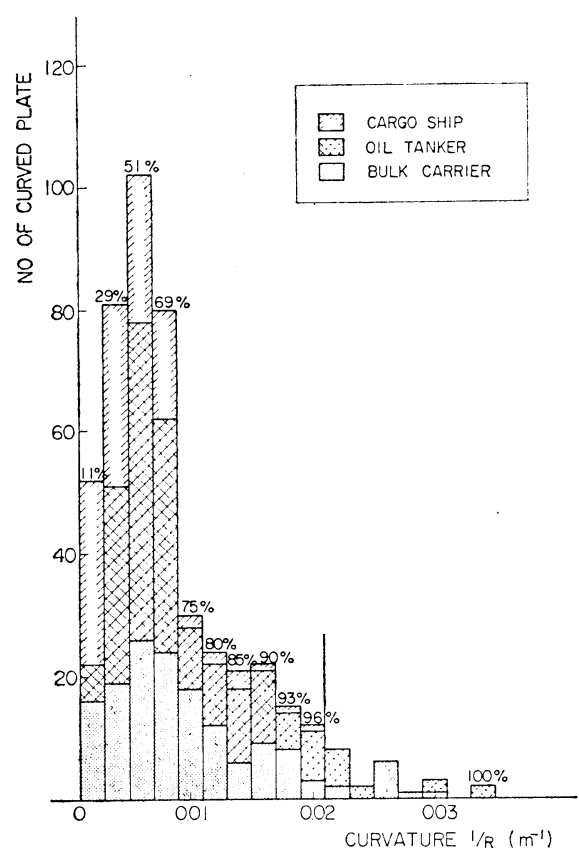

Fig. 3 縦方向の曲率分布（枚数）

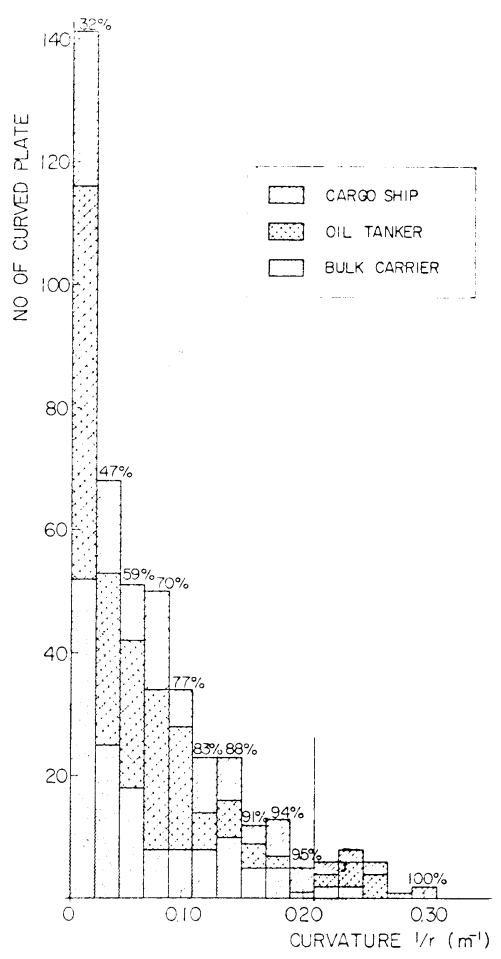

Fig.4 横方向の曲率分布（枚数）
このようにして求めた曲り外板の形状を Fig. 2 に示す。 同図に颃いて曲率半径は船体の舷外に凸の形状に対応する ものを正としている。従って, 図の第 1 象限と第 3 象限, および第 2 象限と第 4 象限に位置するものは形状的にはそ れぞれ同一系列に属するものである。

また，Fig. 3 および Fig. 4 は，それぞれ板の長さ方向お よび幅方向の曲率の枚数分布を求めたものである。なお， 210, 000 DWT 型タンカーの資料については, 他の 2 船種 の片舷分全曲り外板数とオーダーを合わせるために，ラン ダム抽出数を 2 倍して，全数 200 枚として集計した。

以上の集計の結果から，次のようなことが明らかとなっ た。

（1）板長さ方向の曲率 $(1 / R)$ は一般に極めて小さい。 全数の約 $80 \%$ は $0.012 \mathrm{~m}^{-1}$ 以下, $95 \%$ が $0.02 \mathrm{~m}^{-1}$ 以 下である。

（2）板幅方向の曲率 (1/r) については，その約 $80 \%$ が $0.11 \mathrm{~m}^{-1}$ 以下, $95 \%$ が $0.2 \mathrm{~m}^{-1}$ 以下の範囲に入る。

（3）全曲り外板の内，約 $75 \%$ は $R$ と $r$ 同符号，す なわち枕型（ドーナッ外型）の曲げ形状であり，約 $25 \%$ が鞍型（ドーナッ内型）の形状である。

（4）縦, 横両曲率半径の比が 1 5 の範囲の板は, 全 数の約 $35 \%, 5 \sim 10$ のものが約 $27 \% ， 10$ を越すものが 約 $38 \%$ である。またこの比が小さい範囲のものは一般に 縦横曲率半径の值が共に大きく極めて浅い曲げであり，r の小さいものは一般にRが大きくシリンダーに近い。

なお，加工すべき船体曲面の形状は非数学的なものであ り，そのままで取り扱う事は困難である。そこで，第 1 段 階としては船体曲面を代表する幾系統かの標準曲面を準

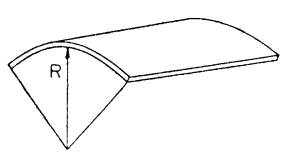

(a) CYLINDER

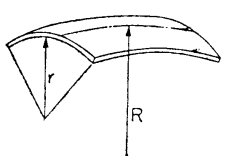

(c) DOUGHNUT-OUTSIDE

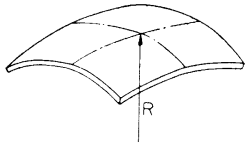

(b) SPHERE

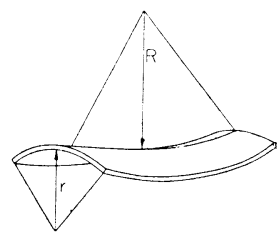

(d) DOUGHNUT-INSIDE

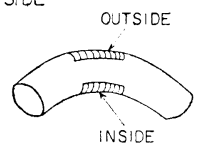

DOUGHNUT

Fig. 5 船 体 標準曲面 
備し, これら標準曲面の曲げ加工について種々の検討を行い, 引続いて, 第 2 段階として, 船体曲面の曲げ加工 について検討する。

ここでは, 標準曲面として Fig. 5 に示すシリンダー型, 球型, ドーナッ外型(枕型) 拉よびドーナッ内型(鞍型) を用いる。

\section{4 基 礎 実 験}

船体外板の曲げ作業に多点プレスを導入しようとする試みは約 10 年前に行われた1)。しかし，多点プレス つヘッドがボールジョイントの型式でニニバーサルに回転可能なニニバーサル多点プレスはこれまでの多点プレ ス1)とは異なり新しい概念による曲げ加工方式であり，まだ実用化された例は報告されていない。そこで，本法 を鋼板の曲げ加工に適用するに当っては，次に述べる項目に対して実験的，理論的に検討を行う必要がある。

a) 成型結果の再現性が良好かどうか

b）成型曲面の平滑度（フェアネス）が良好かどうか

c）プレス荷重の押し切りの影響

d）曲げ加工後のスプリングバック量の大きさと曲面形状の関係

e ）多点ピストンのピッチの選定

f）加熱曲げの可能性の検討

以上の項目を検討するために，小形の単一曲げ型による基礎実験を行った。

\section{1 単一曲げ型による基礎実験}

4.1.1 実験装置执よび方法

実験に使用した単一曲げ型は Table 4 に示すように曲率半径を変えたシリンダー型 2 種, ドーナッ内型, 外型 および球型各 1 種である。各下型の曲率半径は上型の曲率半径よりも，それぞれ $5 \mathrm{~mm}$ 讨大きくし，板厚 $5 \mathrm{~mm}$ の試験片をプレスした場合に完全にすきまがなくなるようにした。試験片の板厚が $5 \mathrm{~mm}$ 以下の場合に は薄いりん青銅板を重ねて合計板厚が $5 \mathrm{~mm}$ になるようにした。

これらの曲げ型を 10 トン構造物試験機に取り付けて実験した。プレス荷重および变形はそれぞれロードセル 小よび電気的変位計で検出して $X Y$ レコーダーに記録した。プレス後の残留変形は 1/100 mm ダイヤルゲージ で計測した。

これらの各曲げ型でのプレス実験の他に, 曲げ加工性に及ぼす単一曲げ型と多点ピストンヘッドとの相違を調 ベるために, これらの単一曲げ型に円板型ワッペン（直径 $25 \mathrm{~mm}$, 板厚 $2 \mathrm{~mm}$ ) を, そのピッチを变えて受圧面 に貼布したものについても実験した。Fig.6 はシリンダー型（A）にワッペンを貼布した曲げ型を試験機にセッ トした例である。

Table 4 単一ヘッド曲げ型

\begin{tabular}{|c|c|c|}
\hline & $\begin{array}{c}\text { 縦 曲率半径 } \\
(\mathrm{mm})\end{array}$ & $\begin{array}{c}\text { 横曲率半径 } \\
(\mathrm{mm})\end{array}$ \\
\hline シリンダー型 (A) & 570 & $\infty$ \\
\hline シリンダー型 (B) & 300 & $\infty$ \\
\hline ドーナッ外型 & 800 & 400 \\
\hline ドーナッ内型 & 800 & -400 \\
\hline 球型 & 570 & 570 \\
\hline
\end{tabular}

Table 5 材料の機械的性質

\begin{tabular}{|c|c|c|}
\hline 板 $(\mathrm{mm})^{\text {厚 }}$ & $\begin{array}{c}\text { 降伏応力 } \\
\left(\mathrm{kg} / \mathrm{mm}^{2}\right)\end{array}$ & $\begin{array}{l}+ソ ク ゙ \text { 率 } \\
\left(\mathrm{kg} / \mathrm{mm}^{2}\right)\end{array}$ \\
\hline 2. 0 & 20.0 & 18,200 \\
\hline 3. 2 & 17.2 & 18. 600 \\
\hline 4.5 & 24.8 & 20.000 \\
\hline 5.0 & 18. 2 & 18. 900 \\
\hline
\end{tabular}

㬰験に用いた試験片の大きさは $310 \mathrm{~mm} \times 290 \mathrm{~mm}$ の矩形板である。また一部比較のために直径 $300 \mathrm{~mm}$ の円板試験片も用いた。各材料の機械的性質を Table 5 に示す。

4.1 .2 実験結果および考察

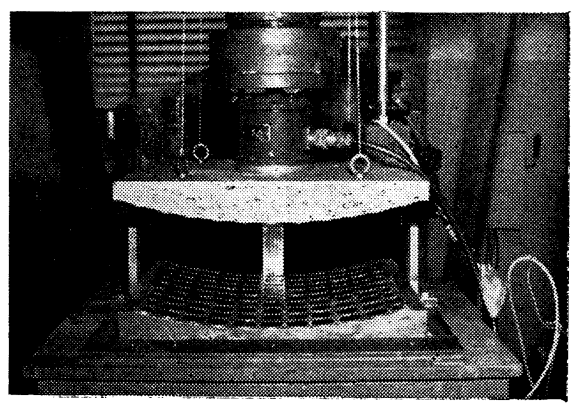

Fig. 6 小形試験装置 


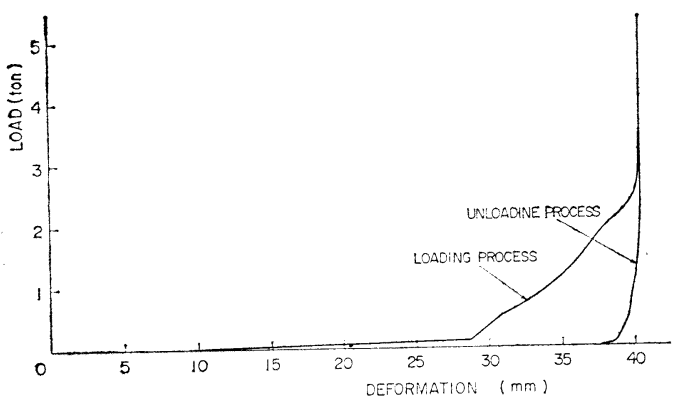

Fig. 7 プレス荷重〜变位

プレス時の荷重〜変形曲線の一例を Fig. 7 に示す。 変形が相当進むまでプレス荷重は低く, 変形の最終 段階近くで荷重は急増し, 最後はいわゆる押し切り 状態になって変形が全く進まずに荷重のみが増加す る。プレス荷重の押し切り効果を調べるために，最 高プレス荷重が 5 トンの場合と 10 トンの場合の寒 験を行った。実験結果より，両者は共にプレス後の 仕上り状態（フェアネス）は良好であり，スプリン グバック量にも差異のない事が明らかになった。

単一曲げ型による曲げ加工後の仕上り状態（フェ アネス）は極めて良好であり，実験結果の再現性も

十分であった。

実験結果の1例としてシリンダー型およびドーナッ内型による結果を Figs. 8，9 亿示す。これらの図は試験 片中央の变位を板厚に対して整理したものであり，シリンダ一型の場合には他の曲げ型のものに比べて板厚の影 響が大きく現われている。各曲げ型に円板形ワッペンを貼布した場合の実験結果は，ワッペンを使用しない場合 とほとんど変わらないが，傾向的にワッペンのピッチを増大するとスプリングバック量はわずかではあるが増加 するように見受けられる。また球型, ドーナッ型のように縦横両曲率を持つ曲げ型の場合には, 貼布ワッペンの ピッチを大きくすると板厚が $3 \mathrm{~mm}$ 以下の薄板の場合には, Fig. 10 に示すように, 試験片の周辺部に凹凸のし わが発生した。このような曲げ型による板曲げでは，Fig.10 に示すように試験片の周辺に沿った方向に大きな 圧縮応力が生じ，板厚が薄くてワッペンのピッチが大きい場合にはワッペン間で座屈が生じるためである。

試験片に発生した座屈を解析するに先立って，まず，簡単のために Fig.11 に示す半径 $r_{0}$ の円板を曲率半径 $R$ の球型に曲げた場合の試験片に生じる歪分布を解析する。 $r$ 方向の面内変位を $u, z$ 方向のたわみをwとする と, 雨は

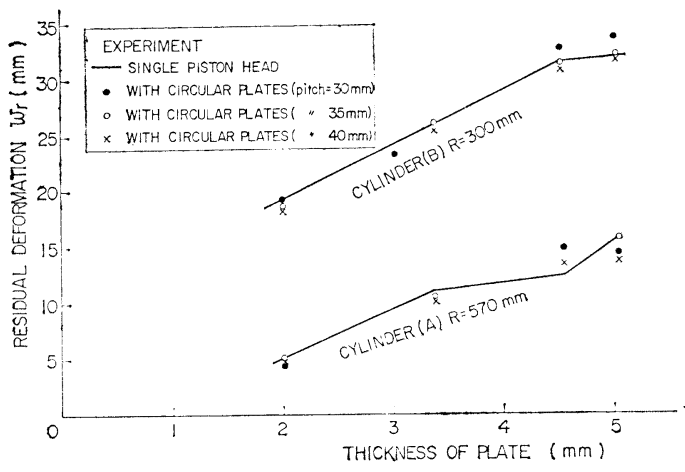

Fig. 8 シリンダー型曲げ試験

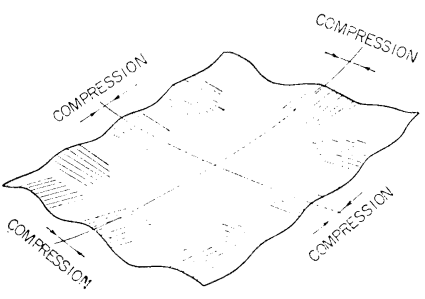

Fig. 10 座 屈変 形

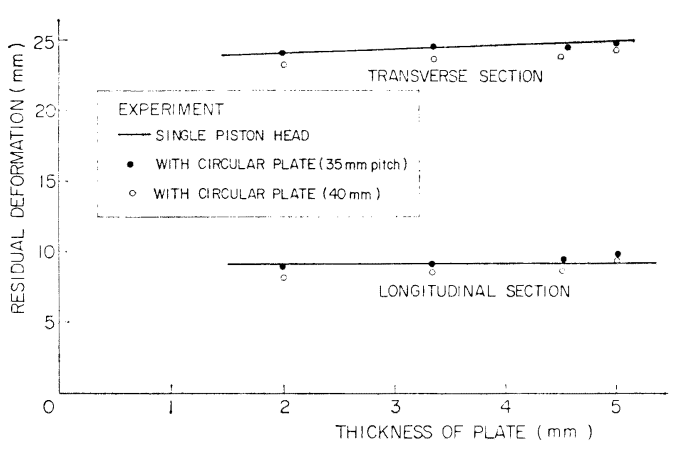

Fig. 9 ドーナツ内型実験

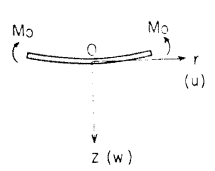

(a)

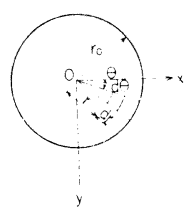

(b)

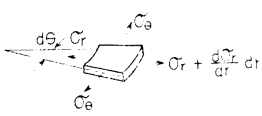

(c)

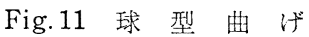




$$
\begin{aligned}
& \varepsilon_{r}=\frac{d u}{d r}+\frac{1}{2}\left(\frac{d w}{d r}\right)^{2} \\
& \varepsilon_{\theta}=\frac{u}{r}
\end{aligned}
$$

平衡条件式は

$$
\sigma_{r}-\sigma_{\theta}+r \frac{d \sigma_{r}}{d r}=0
$$

今, 試験片を球型に曲げるので

$$
w=R-\sqrt{R^{2}-r^{2}}
$$

境界条件として，r=r $r_{0}$ で $\sigma_{r}=0$ を考え, ポアソン比の影響を無視すると

$$
\left.\begin{array}{l}
\varepsilon_{r}=\frac{r_{0}^{2}}{16 R^{2}}\left\{1-\left(\frac{r}{r_{0}}\right)^{2}\right\} \\
\varepsilon_{\theta}=\frac{r_{0}^{2}}{16 R^{2}}\left\{1-3\left(\frac{r}{r_{0}}\right)^{2}\right\}
\end{array}\right\}
$$

上式は試験片が弾性変形する場合の雨分布である。一方, 実際の試験片では部分的には塑性変形が生じている が，その歪分布は弾性変形とみなした場合とあまり相違しないと考えられる。

次章の大形実験で矩形試験片 $(966 \mathrm{~mm} \times 966 \mathrm{~mm} \times 18.5 \mathrm{~mm})$ で測定した球 型 曲げの膜歪と計算值の比較を Fig. 12 に示すが, 両者は比較的良く一致している。

座屈によるしわが発生した試験片の円周歪 $\left(\varepsilon_{\theta}\right)$ を上式を用いて 計算すると, 約 $8,800 \times 10^{-6}$ の圧縮歪となり, これが薄板試験片に 凹凸のしわを発生させた原因であることがわかる。従って実船の外 板の曲げ加工では本実験で観測された座屈を発生させないための配 虑, すなわちユニバーサル多点プレスのピストンヘッドのピッチを 選ぶにあたって座屈が発生しない様に留意する事が必要である。

本実験で観測された座屈が発生する限界歪は次式で与えられると 考える。

$$
\varepsilon_{\theta}=c\left(\frac{t}{l}\right)^{2}
$$

ここで $t:$ 板厚, $l:$ 支持間距離（ワッペンのピッチ）, $c:$ 定数
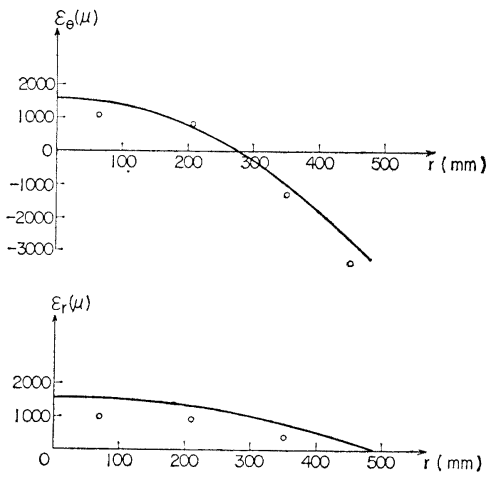

Fig. 12 球型曲げの膜歪

上式の定数 $c$ を戦密に計算することは難しいが, 実駼結果より板厚 $3 \mathrm{~mm}$ 以下の薄板に座屈が生じている事, およびワッペンのピッチの限界が $30 \mathrm{~mm}$ である事を考慮すると, 実験定数として

$$
c=8.8 \times 10^{-1}
$$

実船の外板では被加工板の曲率半径がさらに大きなものとなるので, 円周方向の圧縮応力は減少して座屈しに くくなり, 従って多点ピストンヘッドのピッチはかなり大きくする事ができる。座屈に対して最も厳しい場合と して, 板厚 $12 \mathrm{~mm}$ の鋼板 $(1 \mathrm{~m} \times 1 \mathrm{~m})$ を曲率半径 $5 \mathrm{~m}$ の球型に曲げた場合の円周䟚は（6）式より

$$
\varepsilon_{\theta}=1400 \times 10^{-6}
$$

座屈が生じないためのピストンヘッドのピッチの限界は (7), (8), (9) 式より

$$
l=300 \mathrm{~mm}
$$

従って, 実船の外板の曲げ加工に用いる多点ピストンのピッチは多少の余裕をみて $250 \mathrm{~mm}$ 程度にすれば本実 験で発生したような座屈は発生しないものと考えられる。

\section{2 加熱曲げ実験}

鋼板を加熱すると降伏応力およびヤング率が大幅に減少する。従って, 加熱板の曲げ加工によってプレス荷重 およびスプリングバック量が減少するといら利点が考えられる。そこで加熱試験片の曲げ加工実験を行って温度 の影響を調査した。

\subsection{1 実験装置执よび方法}

加熱曲げに用いた実験装置はFig.13 に示す門型フレームに 3 トンのスクリュージャッキを取り付けて試験片, 支持台および負荷棒を加熱炉でお括って，プロパンガスによる加熱曲げを行った。実験に用いた試験片の寸法は $200 \mathrm{~mm} \times 200 \mathrm{~mm} \times 5 \mathrm{~mm}$ で, その材料の機械的性質は Table 5 に示す。実験は 2 点支持中央集中荷重で行い, 


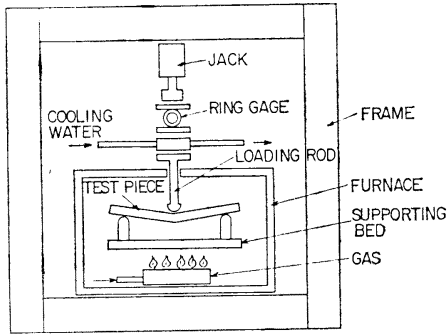

Fig.13 加熱実験装置

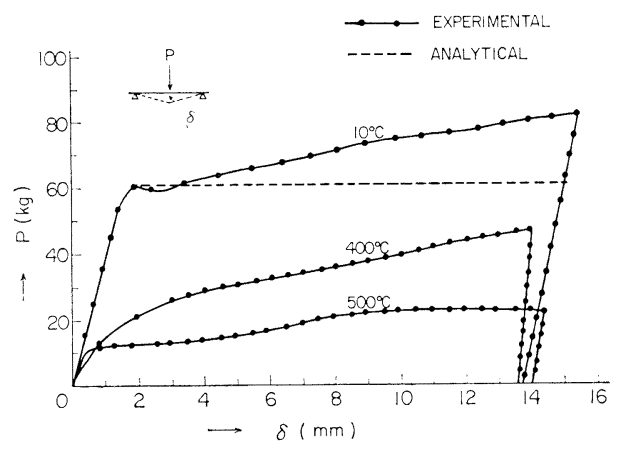

Fig.14 熱間曲げ実験結果

荷重はリングゲージ，たわみは 1/100 mm のダイアルゲージで計測した。

加熱曲げに対しては温度管理を厳密に行うことが必須の条件であり, 特に熱間曲げ加工後の冷却過程で均一徐 冷を行わなければ熱応力による変形のために実験結果の再現性は得られなくなる。本実験ではこの点に留意し て，均一冷却ができるよらに装置全体を炉中に収納した。

\section{2.2 実験結果执よび考察}

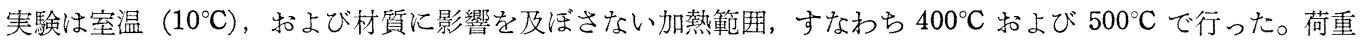
と変形の計測值を Fig. 14 に示す。同図より明らかなよらに，プレス荷重特よびスプリングバック量は試験温度 が高くなると大幅に減少する。これは材料の機械的性質が温度の影響を受け, 高温で降伏応力拉よ゙ャング率が 大幅に低下寸るからである。

両端で単純支持され，スパン中央に集中荷重が作用する帯板の弾塑性挙動の解析をすると，スパン中央のたわ みは次式で与えられる2)。

$$
\begin{aligned}
& w=\frac{2}{9} K_{e} l^{2} A\left[3\left(1-\frac{1}{A}\right)\right]^{1 / 2}(1+2 A)-\frac{20}{27} K_{e} l^{2} A^{2} \\
& \text { ここで } \quad A=M_{P} / M_{l}=2 M_{P} / P l \\
& K_{e}=2 \sigma_{Y} / t E \\
& P: \text { 中央集中荷重 } \\
& M_{P}: \text { 全塑性モーメント }
\end{aligned}
$$

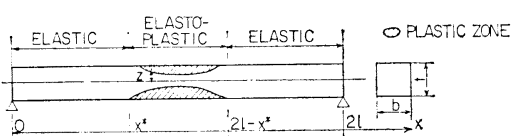

Fig. 15 带板

材料の歪硬化はないと仮定して室温に拉ける試験の解析結果を

Fig. 14 に示す。

なお，鋼材の材質に悪影響を及ぼさない範网 $\left(400^{\circ} \mathrm{C} \sim 500^{\circ} \mathrm{C}\right)$ で加熱すると，スプリングバック量は減少するが零にはならず, 加熱を併用しても 2 回押しの問題, スプリングバック量のフィー

ドバックの問題が残り, しかもプレスのたびに加熱が必要となるのでメリットが少ない。さらに, 複雑な NC 機 構に熱を伝達させないような加熱炉は極めて高価なものになるものと思われる。

これらの検討の結果, ニニバーサル多点プレス方式では加熱は併用せず，泠間プレスで曲げ加工を行うことに した。

\section{5 実用化実 験}

小形模型による基礎実験によって成型曲面のフェアネスの状況，ピストンヘッドのピッチ等に関する基礎的な 資料が得られたので，次にピストンヘッドの大きさが実物大に近い大形ニニバーサル多点プレス模型を用いて小 形実験によって得られた結果の確認扎よび定量的な結果を得るための実用化実験を実施した。

\section{1 実験装置および方法}

第 1 次大形実験装置として製作したニニバーサル多点プレスの全体図を Fig. 16 に，ニニバーサルピストンを Fig. 17 に示す。本装置の多点ピストンはスクリニージャッキであり，上・下各ジャッキの高さを手動で位置決 めする方式である。多点ピストンの配置は Fig. 18 に示すようにそのピッチを $141 \mathrm{~mm}$ あるいは $200 \mathrm{~mm}$ のい 


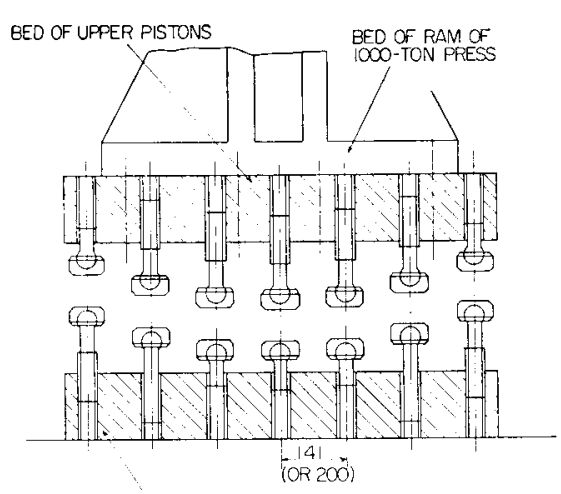

BED OF LOWER PISTONS

Fig. 16 装置 断 面図

NO OF CYLINDERS $7 \times 7=49$

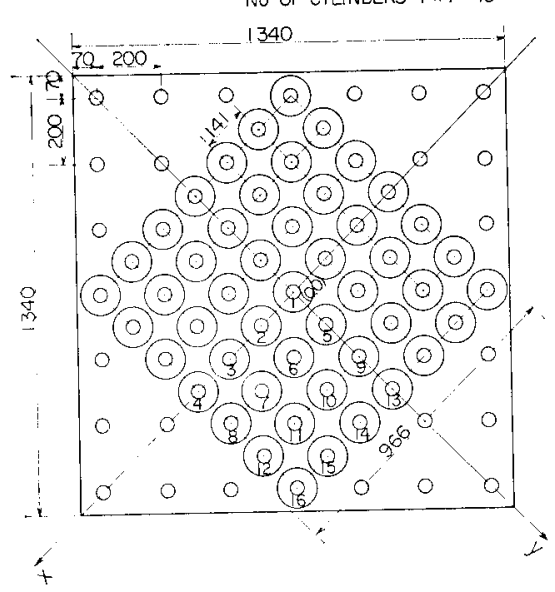

Fig. 18 ピストンヘッド配置図

ずれかにしてピストンベッドに取付ける。ピストンベ ッドは Fig.19 に亦すよに 1,000 トンプレスのラム ヘッドル取付けて衰験を行った。試験装狊の主要目を Table 6 に示与。

試験片の曲げ曲率は実船外板の曲率の大きさの分布 にスプリングバック量を加味して横䏺り曲率半径 $R_{x}$ $=3,000 \sim 6,000 \mathrm{~mm}$, 縦曲门半径 $R_{y}=6,000 \mathrm{~mm}$ 学目 安とし, シリンダー型, 球型, ドーナツ外型扣よびド 一ナッ内型の 4 種類の曲面について試験片板厚と縦横 曲率半径の組合わせをTable 7 に示すと招りにして実 験を行った。このシリーズ実験に劣けるピストンピッ チは $141 \mathrm{~mm}$ を標準とし, 試験片の寸法は $966 \mathrm{~mm}$ $\times 966 \mathrm{~mm}$ とした。

曲げ加工中のプレス荷重と変位はプレスの油生計恕 よび差動トランスを介して XYレコーダーに記録し た。また球面, ドーナッ外面・内面の各 1 枚の試験片 の表裏に電気抵抗線歪計を貼布して，曲げ加工中の歪

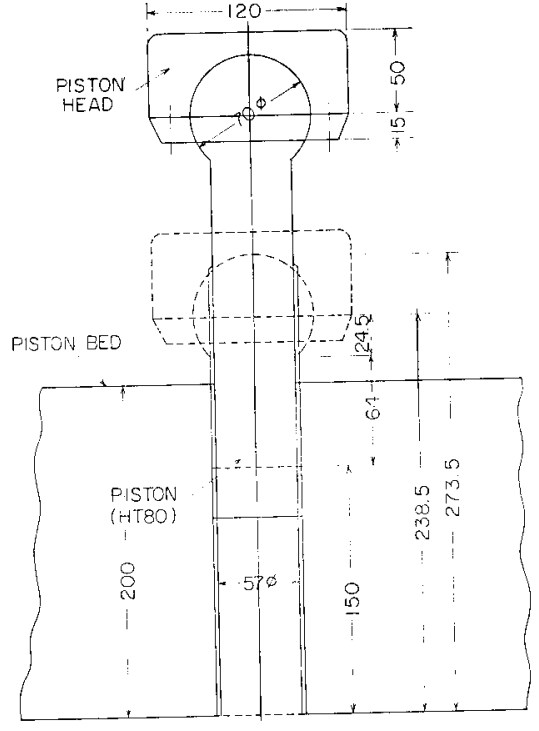

Fig.17 下部スクリュージャッキ

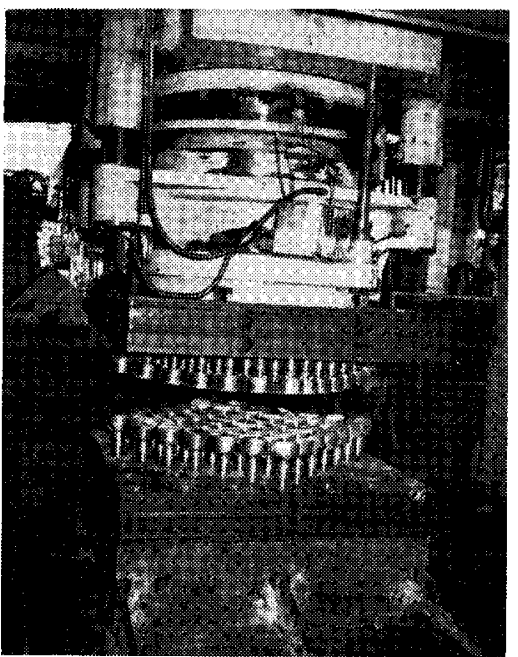

Fig. 19 ユニバーサル多点プレス装置

Table 6 第 1 次大形試験装置要目

\begin{tabular}{|c|c|}
\hline $\begin{array}{l}\text { ピトン人ッド } \\
(\text { 上, 下各) }\end{array}$ & $1,340 \mathrm{~mm} \times 1,340 \mathrm{~mm} \times 200 \mathrm{~mm}$ \\
\hline $\begin{array}{l}\left.\text { 七́ }^{\circ} \text { (上, 下各 }\right)^{\prime} \\
\text { 数 }\end{array}$ & 7 行 $\times 7$ 列 $=49$ 本 \\
\hline ピストン閏隔 & $141 \mathrm{~mm}, \quad 200 \mathrm{~mm}$ \\
\hline ピストン様式 & $\begin{array}{l}57 \phi \times 274 \mathrm{~mm} \text { (回転球 } 70 \phi) \\
\text { スクリ二ー式(手動位置制御方式) } \\
\text { 材質 : HT } 80\end{array}$ \\
\hline ピストンヘッド & $\begin{array}{l}120 \phi \times 50 \mathrm{~mm} \\
\text { ユニバーサル回檕支持機構方式 } \\
\text { 材質 : SS } 41\end{array}$ \\
\hline
\end{tabular}


Table 7 曲げ加工実験シリーズ

（a）シリンダー型

\begin{tabular}{rrr|c}
\hline \hline \multicolumn{2}{c|}{$t(\mathrm{~mm})$} & $R(\mathrm{~mm})$ \\
\hline 5.0 & & & 4,000 \\
12.5 & 19.5 & 25 & 3,000 \\
& 19.5 & & 5,000 \\
\hline
\end{tabular}

（b）球 型

\begin{tabular}{ccc|c}
\hline \multicolumn{3}{c|}{$t(\mathrm{~mm})$} & $R(\mathrm{~mm})$ \\
\hline 12.2 & 18.5 & 24.6 & 3,000 \\
12.2 & 19.2 & 25.0 & 4,000 \\
& 19.2 & & 5,000 \\
\hline
\end{tabular}

(c) ドーナツ外型

\begin{tabular}{|c|c|c|c|c|}
\hline \multicolumn{3}{|c|}{$t(\mathrm{~mm})$} & \multirow{2}{*}{$\frac{R_{x}(\mathrm{~mm})}{3,000}$} & \multirow{2}{*}{$\frac{R_{y}(\mathrm{~mm})}{6,000}$} \\
\hline 12.2 & 19. 2 & 25.0 & & \\
\hline \multirow[t]{4}{*}{12.2} & 18. 5 & 24.6 & 3,000 & 6,000 \\
\hline & 19. 2 & & 3,000 & 5,000 \\
\hline & 19. 2 & & 4,000 & 5,000 \\
\hline & 19. 2 & & 4,000 & 6,000 \\
\hline
\end{tabular}

（d）ドーナツ内型

\begin{tabular}{ccc|c|c}
\hline \hline \multicolumn{2}{c|}{$t(\mathrm{~mm})$} & & $R_{x}(\mathrm{~mm})$ & $R_{y}(\mathrm{~mm})$ \\
\hline 12.2 & 18.5 & 25.0 & 3,000 & 6,000 \\
& 19.3 & & 3,000 & 5,000 \\
19.6 & & 4,000 & 5,000 \\
19.2 & & 4,000 & 6,000 \\
\hline
\end{tabular}

状態を Table 9 に示す。

第 2 次大形試験装置では $1 \mathrm{~m} 350 \times 1 \mathrm{~m} 350$ の試験片を用いて加圧順序が成型結果に及ぼす影響を調べる実験 および第 1 次実験（Table 7) を拡張したシリーズ実験を行った。

実船の外板を曲げ加工する場合には鋼板は長尺物であるために実用機のプレス長さよりも大きくなり重複押し
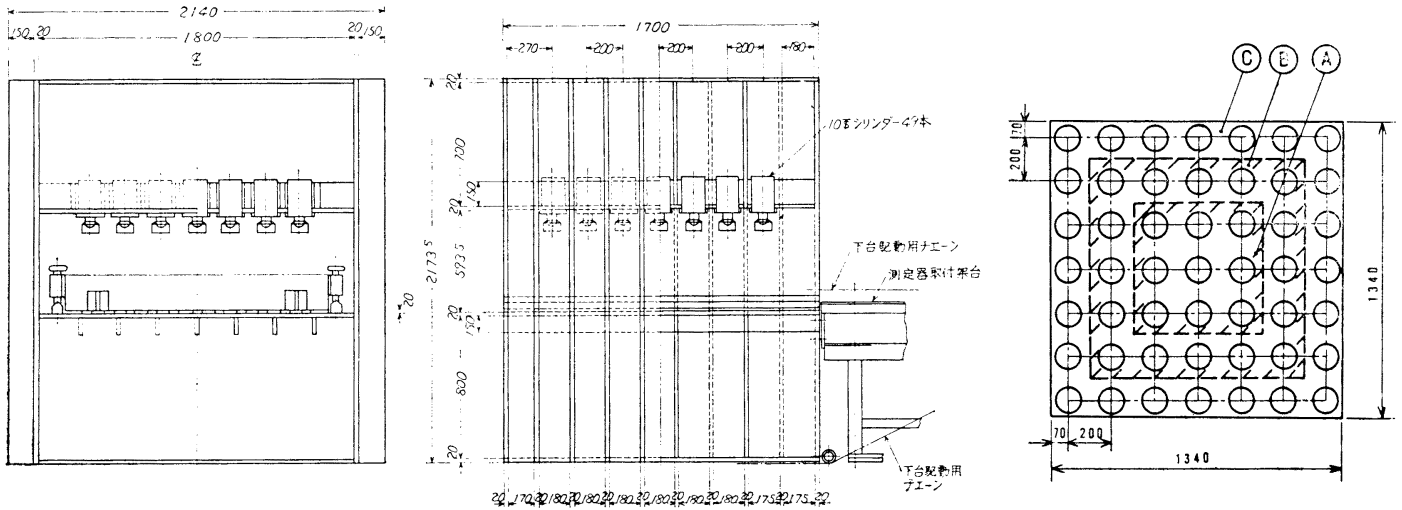

(a) 500 トンュニバーサル多点プレス

(b) 多点ピストンのブロック分割

Fig. 20 ユニバーサル多点プレス装置 


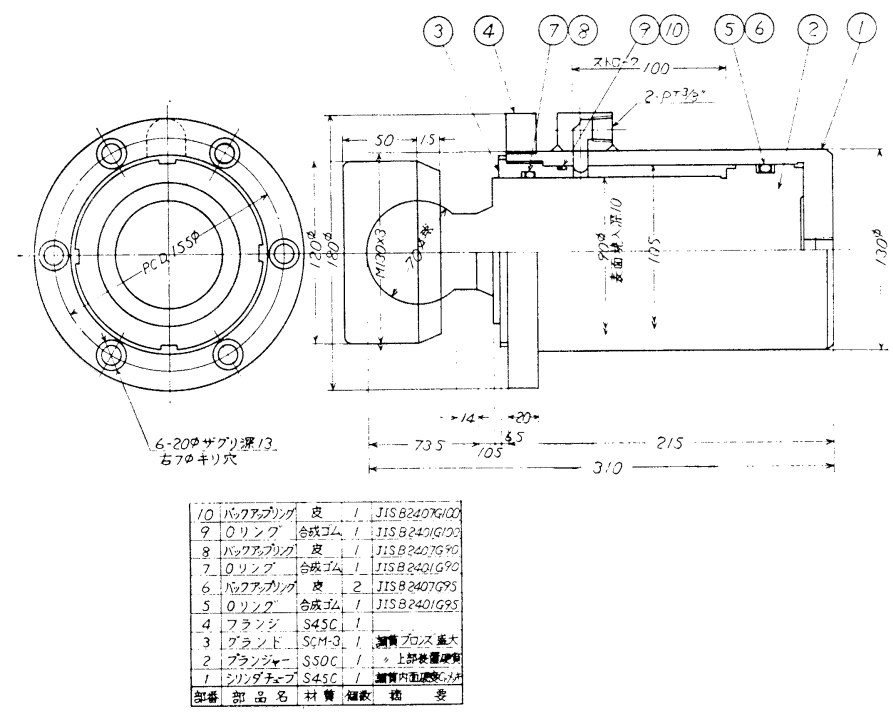

Fig. 21 上部油圧 ジャッキ

Table 9 プレスの加圧順序例 $(\mathrm{A} \rightarrow \mathrm{B} \rightarrow \mathrm{C})$

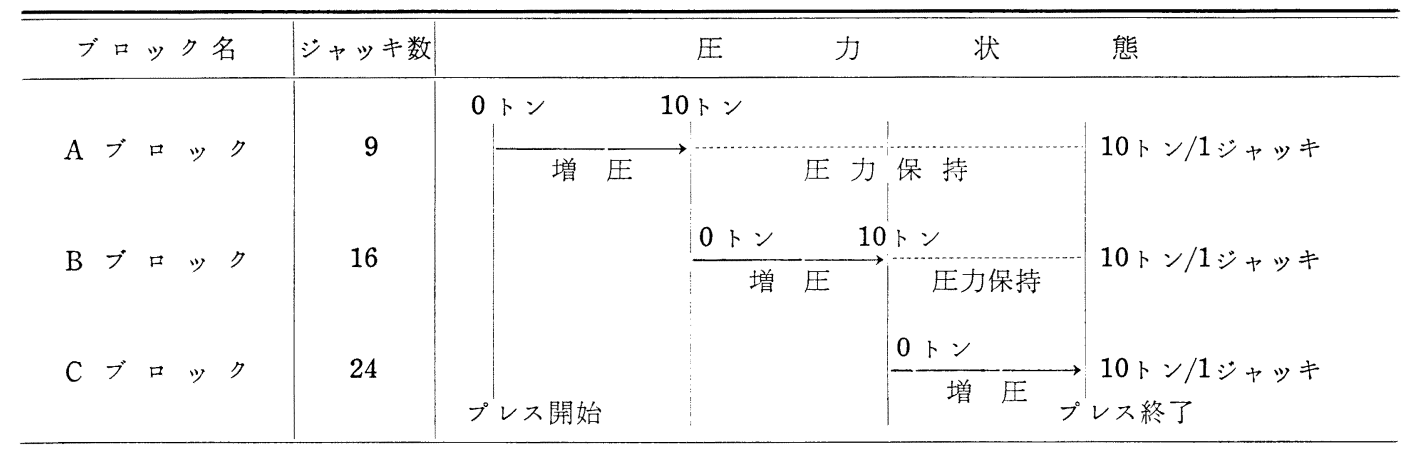

をして所要の形状に曲げ加工することが必要になる事もあると考えられる。そこで重複押しの実験は板厚 $16 \mathrm{~mm}$ の長尺物の試験片をシリンダー型 $(R=4,000 \mathrm{~mm})$ に曲げる場合の重複代を板の長手方向（シリンダー軸方向） にピストンヘッド 2 ピッチ分， 1 ピッチ分拈よび 0 ピッチ分の 3 ケースに変えた実験も実施した。

曲げ加工後の試験片の曲面形状を電気的変位計により計測し, 得られたアナログデータは A-D 变換器でディ ジタルデータに変換し，紙テープおよびモニター用のプリンターに記録した。紙テープ上のディジタルデータは 小形電子計算機（HITAC-10）で処理し，試験片の曲面形状を計算した。

\section{2 実験結果および考察}

（1）曲面のフェアネスおよび再現性

ユニバーサル多点プレスによる実験結果の再現性は良好であり, かつ成形曲面の平滑度, すなわちフェアネス は曲面の種類（シリンダー型, 球型, ドーナツ型）にかかわらず極めて良好であった。

(2) ピストンピッチの影響

大形実験ではニニバーサル多点プレスのピストンピッチは, 小形実験の結果を参考にして, 試験片に座屈が生 じないように考慮して設計されたが，実験の結果，多点ピストンのピッチが $141 \mathrm{~mm}$ の場合はもちろん，200 $\mathrm{mm}$ の場合にもフェアネスは良好であり, 小形実験の薄板に発生した座屈による周辺のしわは全く発生しなかっ た。

（3）スプリングバック量と形状誤差

曲げ加工後の試験片の曲面形状は，試験片を49 分割した中央点の值を零とした相対高さで整理記録した。プ 
Table 10 プレス後の曲面形状例 (mm)

\begin{tabular}{c|c|c|ccc}
\hline \hline 曲 型 & 曲率 半 径 & 試 験片 寸法 & ピ & 少 \\
\hline ドーナッ内型 & $5,000 \times 10,000$ & $1,350 \times 1,350 \times 15.9$ & \multicolumn{2}{|c}{200}
\end{tabular}

曲面 形 状

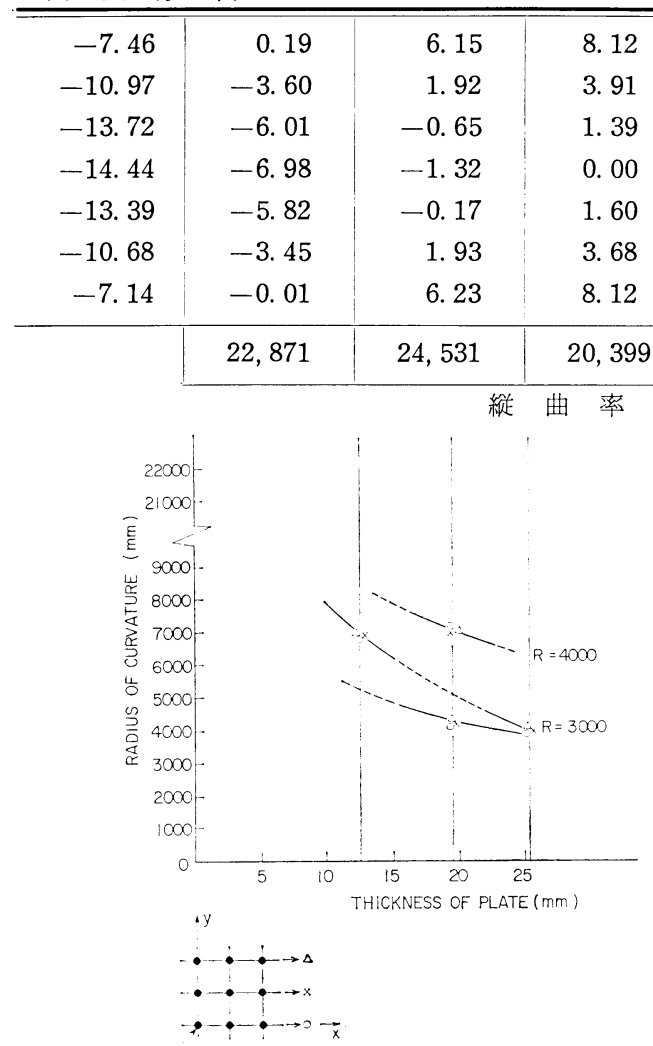

CENTER OF PLATE

Fig. 22 曲率と板厚とスプリングバック後の曲率 (シリンダー型)

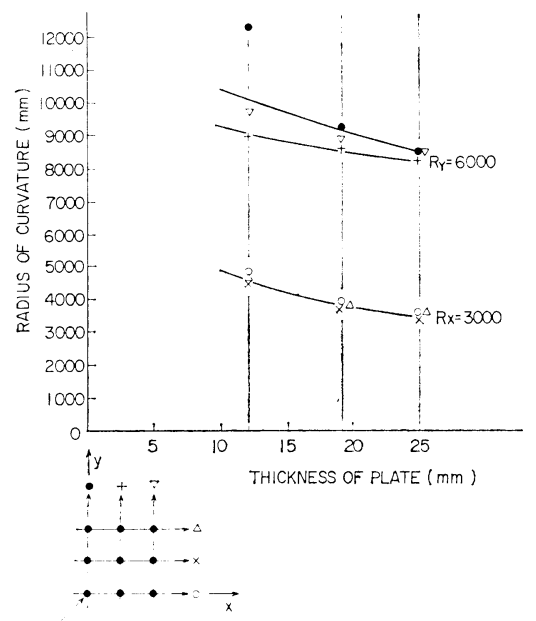

CENTER OF PLATE

Fig. 24 曲率と板厚とスプリングバック後の曲率 (ドーナツ外型)

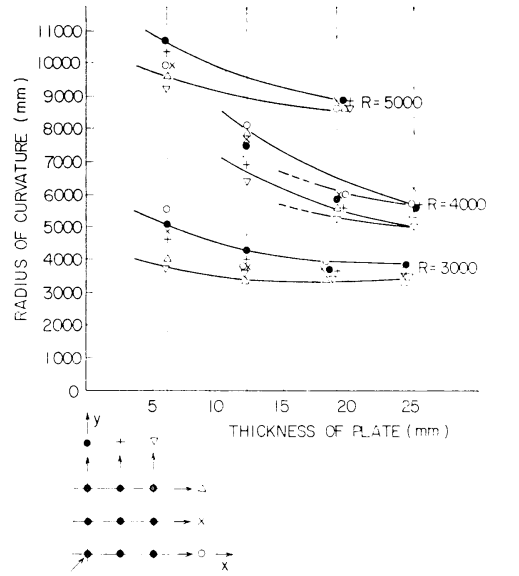

CENTER OF PLATE

Fig. 23 曲率と板厚とスプリングバック後の曲率 (球型)

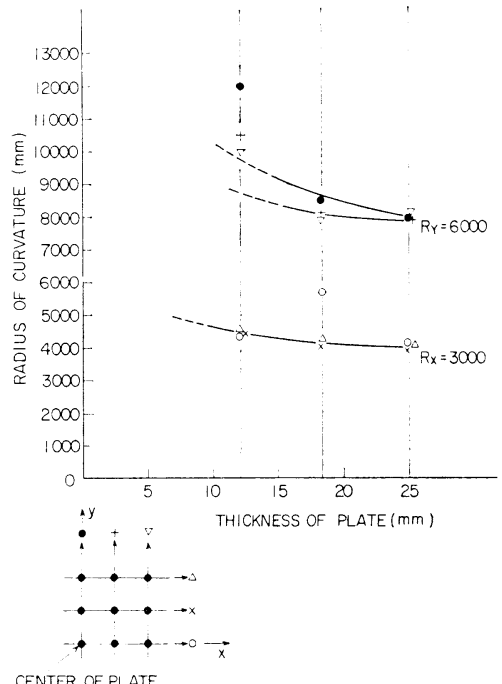

Fig. 25 曲率と板厚とスプリングバック後の曲率 （ドーナツ内型） 


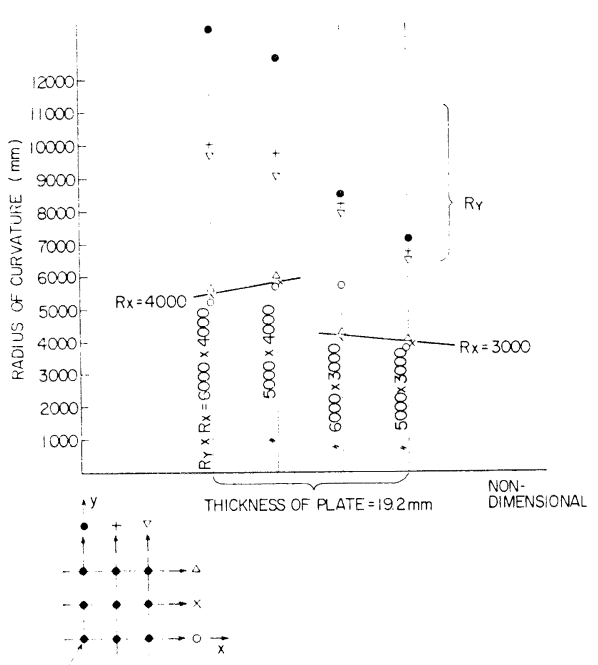

CENTER OF PLATE

Fig. 26 横曲率, 縦曲率の相互影響（ドーナツ外型）
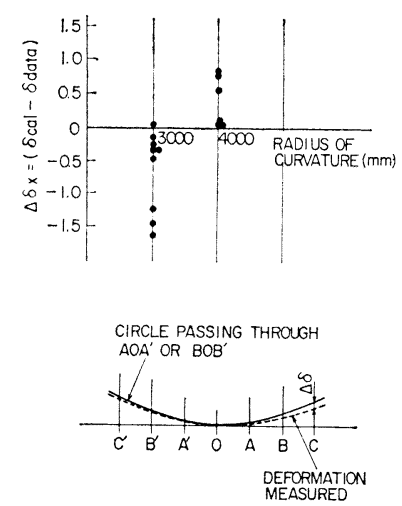

Fig.28 成型曲面のばらつき（シリンダー型）

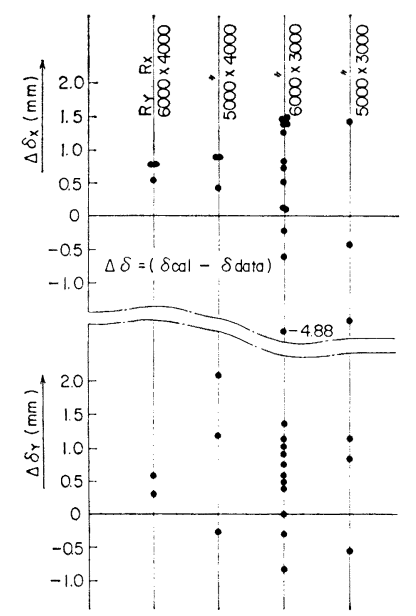

Fig.30 成型曲面のばらつき（ドーナッ外型）

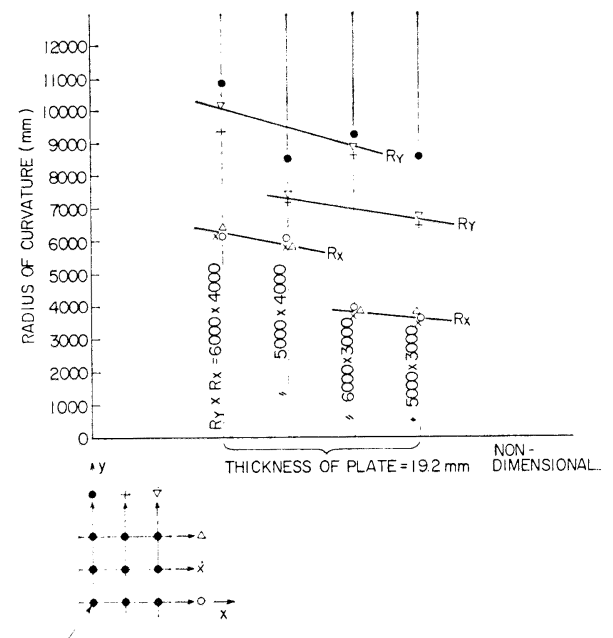

CENTER OF PLATE

Fig.27 横曲率, 縦曲率の相互影響（ドーナツ内型）

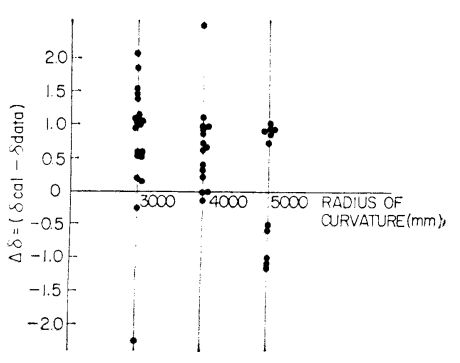

Fig.29 成型曲面のばらつき（球型）

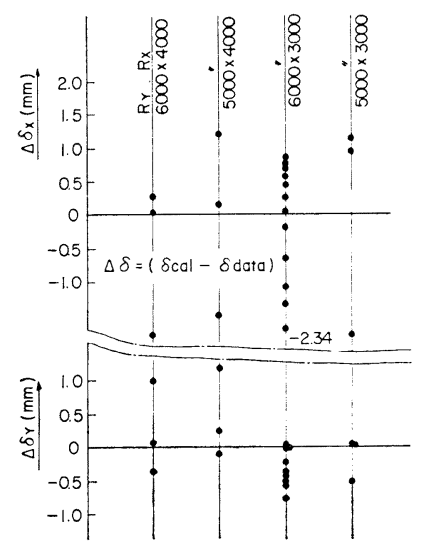

Fig. 31 成型曲面のばらつき（ドーナッ内型） 
ンス後の曲面形状の 1 例を Table 10 に示す。この表に示された計測結果から最小 2 乗法を用いてスプリングバ ック後の曲面の曲率半径を計算し，主要な結果を Fig. 22〜Fig. 25 に示した。同図より明らかなように，スプリ ングバック後の曲率半径は試験片の各断面で注ぼ等しく, その值は試験片の板厚に反比例し, 設定曲率半径に比 例して大きくなる事が明らかになった。

Figs. 26, 27 にはドーナツ型の横曲率および縦曲率の相互干渉の影響を示した。同図より縦横両曲率を持つ場 合にはプレス後の曲面形状は横曲率のみならず縦曲率にも支配されることがわかる。

Fig.28〜Fig.31 はプレス後の $\mathrm{AOA}^{\prime}, \mathrm{BOB}^{\prime}$ のたわ文計測值から，これらの点を通る円孤を計算で求め，その 平均円弧と C 点のたわみ量との差を比較したものであり，そのばらつきも比較的小さいことがわかる。

試験片の端部は Table 10 から明らかなように，注とえぞ曲っていない。これはプレス曲げによる場合の一般 的な傾向であり，板耳を所定の形状に曲げるためにはプレスの周辺部では曲げ型，すなわちピストン高さを余分 に見積って設定する必要がある。

(4) ラップ押しの影響

ラップ押しの実験の結果, ラップ押しをしても成形 曲面のフェアネスは良好であり, ラップ量が少なくて も最終成形状況は良好になる事が明らかになった。 Fig. 32 にはシリンダー型でラップ押しをした場合の たわみ量の推移を示した。

（5）プレス容量

曲げ加工に要する最高荷重は第 1 次実験の場合 300 トンであり，第 2 次実験の場合 500 トンであった。第 1 次実験と第 2 次実験とでプレス荷重に相当な差があ るが，これは第 2 次実験の場合は等分布点荷重である

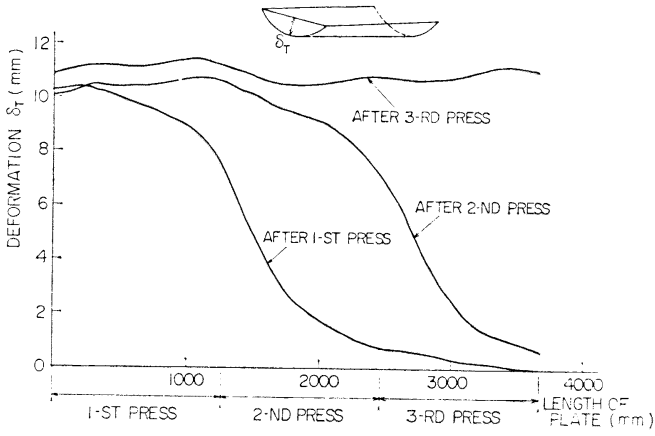

Fig. 32 ラップ押し が, 第 1 次実験の場合は変位型の点荷重型式であり, 荷重型式の差によるものと考えられる。

（6）加圧順序が成形効果に及ぼー影響

ニニバーザル多点プレスの加圧順序が成型効果に及ぼす影響を調ベるために，Fig. 20(b) に示すA，B，C全ブ ロックを同時に加圧した場合， $\mathrm{A} \rightarrow \mathrm{B} \rightarrow \mathrm{C}$ のブロックの順に加圧した場合， $\mathrm{C} \rightarrow \mathrm{B} \rightarrow \mathrm{A}$ のブロックの順に加圧し た場合の 3 種類の加圧順序を選んで実験を行った。

試験片の寸法は $1,350 \mathrm{~mm} \times 1,350 \mathrm{~mm} \times 22 \mathrm{~mm}$ ，降伏応力は $24.8 \mathrm{~kg} / \mathrm{mm}^{2}$ であった。実験に用いた曲げ型 はシリンダー型 $(R=5,000 \mathrm{~mm})$ および球型 $(R=5,000 \mathrm{~mm})$ であった。

プレス後の試験片の形状は，いずれの加圧順序の場合にも非常になめらかであり，曲面のフェアネスは良好で あった。

シリンダー曲げの場合の曲面形状を Table 11 に, 球型曲げの場合を Table 12 に示す。シリンダー曲げの場 合, スプリングパック後の曲率 $(1 / \mathrm{m})$ の大きさは

(1) $\mathrm{A} \rightarrow \mathrm{B} \rightarrow \mathrm{C}$ のブロックの順に加圧する場合

(2) A，B，Cの全ブロックを同時に加圧する場合

(3) $\mathrm{C} \rightarrow \mathrm{B} \rightarrow \mathrm{A}$ のブロックの順に加圧する場合

Table 11 加圧順序の影響 $\quad(\mathrm{mm})$

\begin{tabular}{|c|c|c|c|}
\hline 曲 げ 型 & 曲率半径 & 試 験 片 寸法 & ピッチ \\
\hline シリンダー & 5,000 & $1,350 \times 1,350 \times 21.7$ & 200 \\
\hline 加 圧 & 順 序 & \multicolumn{2}{|c|}{ プレス後の曲率半径 } \\
\hline \multicolumn{2}{|c|}{$\mathrm{A} \rightarrow \mathrm{B} \rightarrow \mathrm{C}$} & \multicolumn{2}{|l|}{6,800} \\
\hline \multicolumn{2}{|c|}{$\mathrm{C} \rightarrow \mathrm{B} \rightarrow \mathrm{A}$} & \multicolumn{2}{|l|}{9,253} \\
\hline \multicolumn{2}{|c|}{$\mathrm{A}, \mathrm{B}, \mathrm{C}$ 同時 } & \multicolumn{2}{|l|}{7,346} \\
\hline
\end{tabular}

Table 12 加圧順序の影響 (mm)

\begin{tabular}{|c|c|c|c|c|}
\hline 曲げ型 & 曲率半径 & \multicolumn{2}{|r|}{ 試験片 寸法 } & ピッチ \\
\hline 球 & 5,000 & \multicolumn{2}{|r|}{$1,350 \times 1,350 \times 21.7$} & 200 \\
\hline 加 田 & \multicolumn{2}{|l|}{ 順 序 } & \multicolumn{2}{|c|}{ プレス後の曲率半径 } \\
\hline \multicolumn{3}{|c|}{$\mathrm{C} \rightarrow \mathrm{B} \rightarrow \mathrm{A}$} & \multicolumn{2}{|l|}{9,149} \\
\hline \multicolumn{2}{|c|}{$A, B, C$ 同時 } & & \multicolumn{2}{|l|}{8,593} \\
\hline
\end{tabular}


Table 13 ドーナッ外型実験結果（等分布点荷重型）

(単位 : $\mathrm{kg}, \mathrm{mm}$ )

\begin{tabular}{c|c|c|c|c}
\hline$r_{0} \times R_{0}$ & $t$ & $\sigma_{Y}$ & $r_{0} / r_{s}$ & $R_{0} / R_{S}$ \\
\hline $4,000 \times 12,000$ & 11.8 & 26.1 & 0.294 & 0.621 \\
$4,000 \times 12,000$ & 15.9 & 24.2 & 0.456 & 0.747 \\
$4,000 \times 12,000$ & 19.3 & 27.5 & 0.524 & 0.787 \\
$4,000 \times 16,000$ & 11.8 & 26.1 & 0.175 & 0.466 \\
$4,000 \times 16,000$ & 15.8 & 24.2 & 0.392 & 0.805 \\
$4,000 \times 16,000$ & 19.3 & 27.5 & 0.498 & 0.864 \\
$5,000 \times 11,000$ & 11.8 & 26.1 & 0.264 & 0.371 \\
$5,000 \times 11,000$ & 15.9 & 24.2 & 0.485 & 0.788 \\
$5,000 \times 11,000$ & 19.3 & 27.5 & 0.576 & 0.824 \\
$5,000 \times 15,000$ & 11.8 & 26.1 & 0.092 & 0.299 \\
$5,000 \times 15,000$ & 15.9 & 24.2 & 0.256 & 0.508 \\
$5,000 \times 15,000$ & 19.3 & 27.5 & 0.326 & 0.484 \\
\hline
\end{tabular}

Table 15 ドーナッ外型実験結果（変位型）

\begin{tabular}{c|c|c|c|c} 
& \multicolumn{4}{c}{ (単位 $: \mathrm{kg}, \mathrm{mm}$ ) } \\
\hline$r_{0} \times R_{0}$ & $t$ & $\sigma_{Y}$ & $r_{0} / r_{s}$ & $R_{0} / R_{s}$ \\
\hline $3,000 \times 6,000$ & 25 & 28.3 & 0.888 & 0.728 \\
$3,000 \times 6,000$ & 19.2 & 26.1 & 0.824 & 0.676 \\
$3,000 \times 6,000$ & 12.2 & 26.2 & 0.652 & 0.581 \\
$3,000 \times 5,000$ & 19.2 & 26.1 & 0.794 & 0.714 \\
$4,000 \times 5,000$ & 19.2 & 26.1 & 0.641 & 0.664 \\
$4,000 \times 6,000$ & 19.2 & 26.1 & 0.619 & 0.594 \\
\hline
\end{tabular}

Table 14 ドーチッ内型実験結果 (等分布点荷重型) (単位 : $\mathrm{kg}, \mathrm{mm}$ )

\begin{tabular}{c|c|c|c|c}
\hline \hline$r_{0} \times R_{0}$ & $t$ & $\sigma_{Y}$ & $r_{0} / r_{s}$ & $R_{0} / R_{s}$ \\
\hline $5,000 \times 5,000$ & 15.9 & 24.2 & 0.766 & 0.615 \\
$5,000 \times 5,000$ & 21.7 & 25.1 & 0.829 & 0.588 \\
$5,000 \times 7,000$ & 11.8 & 26.1 & 0.440 & 0.506 \\
$5,000 \times 7,000$ & 15.9 & 24.2 & 0.522 & 0.503 \\
$5,000 \times 7,000$ & 19.3 & 27.5 & 0.578 & 0.490 \\
$5,000 \times 10,000$ & 15.9 & 24.2 & 0.388 & 0.490 \\
$5,000 \times 10,000$ & 21.7 & 25.1 & 0.536 & 0.578 \\
$5,000 \times 15,000$ & 11.8 & 26.1 & 0.288 & 0.479 \\
$5,000 \times 15,000$ & 15.9 & 24.2 & 0.479 & 0.471 \\
$5,000 \times 15,000$ & 19.3 & 27.5 & 0.331 & 0.356 \\
\hline
\end{tabular}

Table 16 ドーナツ内型実験結果（変位型）

(単位 : $\mathrm{kg}, \mathrm{mm}$ )

\begin{tabular}{c|c|c|c|c}
\hline \hline$r_{0} \times R_{0}$ & $t$ & $\sigma_{Y}$ & $r_{0} / r_{s}$ & $R_{0} / R_{s}$ \\
\hline $3,000 \times 6,000$ & 25.0 & 28.3 & 0.761 & 0.734 \\
$3,000 \times 6,000$ & 18.5 & 28.7 & 0.761 & 0.716 \\
$3,000 \times 6,000$ & 12.2 & 26.2 & 0.714 & 0.736 \\
$3,000 \times 5,000$ & 19.3 & 26.7 & 0.784 & 0.744 \\
$4,000 \times 5,000$ & 19.6 & 24.2 & 0.746 & 0.481 \\
$4,000 \times 5,000$ & 19.2 & 22.1 & 0.813 & 0.550 \\
\hline
\end{tabular}

の順になっている。

一方, 球型曲げの場合には, Fig.20(b) に示す A, B, C 全ブロックを同時に加圧した場合と, C $\rightarrow$ B $\rightarrow$ A ブロ ックの順に加圧した場合とでは，プレス後の曲面形状はほとんど同じである。

これは，油圧ジャッキのブロック分けが同心円状になっているので球型曲げの場合ピストン高さが同心円状だ から, 加压順序を変更しても負荷中の試験片の変形形状にはあまり差がない。一方, シリンダー曲げの場合加圧

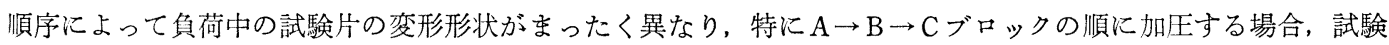
片は最初ドーナッ外型状に変形し変形量が大きめになる。 $\mathrm{C} \rightarrow \mathrm{B} \rightarrow \mathrm{A}$ ブロックの順に加圧する場合, 試験片は最 初ドーナッ内型状に変形し, 変形量が小さめになる。

実船の曲り外板では，一般に，横曲り量が大きく，縦曲り量は小さくて，横曲り量の $1 / 10$ のーダーであ る。したがって，ニニバーサル多点プレスの実用機では上部油圧ジャッキのブロック分けは板幅方向にブロック 分けすると，プレス負荷中の抵抗が少なくなり，プレス容量が小さくてすむものと考えられる。

ドーナッ型の曲げ加工の実験結果を Table 13〜Table 16 に示す。

\section{6 曲げ加工理論}

船体外板を構成する曲面は，通常のプレス加工の場合と異なり，曲率半径が比較的大きく，かつ加工時に大き な伸びを伴わないので, プレス後に生じるスプリングバックを考慮してプレスの曲げ型を設定しなければならな い。

スプリングパック量は曲げの曲率半径, 板の諸寸法, および材料の機械的性質, とくに降伏応力に支配される。 もし設定された曲率半径とスプリングバック後の曲率半径との関係が板の諸寸法と降伏応力の関数として解析的 に求められているならば, この関数を媒介として数回の曲げによって所定の仕上り形状に収束させることが可能 になる。すなわち，第 1 回目の曲げによって生じたスプリングバックを測定し，これを用いて材料常数を求める 
ことができるならば，2 回目はスプリングバックした後に所定の仕上り形状になるよらにスプリングバックを見 込んだ形状に曲げ型を設定することができるはずである。

ここでは船体外板に現われる代表的曲面として，シリンダー型，ドーナッ型および球型について，設定曲面と スプリングバック後の曲面の関係を理論的に求め, 実験結果と比較して理論の妥当性を検討するとともに実験式 についても検討を加える。

6.1 シリンダー 型

シリンダー型とは一方向にのみ曲率を持つ曲面であり, 船体外板から一度にプレスされる範囲を取り出せば, その大部分はシリンダー型と見做すことができる。

(1) 曲げ理論とスペリングバック

平板が弾性限を越えて曲率半径 $r_{0}$ のシリンダーに曲げられた場合を考える。応力分布は Fig. 33 から

$$
\left.\begin{array}{ll}
\sigma=\frac{E}{1-\nu^{2}} \frac{y}{r_{0}} & (0 \leq y \leq \zeta) \\
\sigma=\sigma_{Y} & \left(\zeta \leq y \leq \frac{t}{2}\right)
\end{array}\right\}
$$

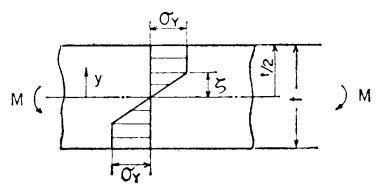

Fig. 33 応力分布

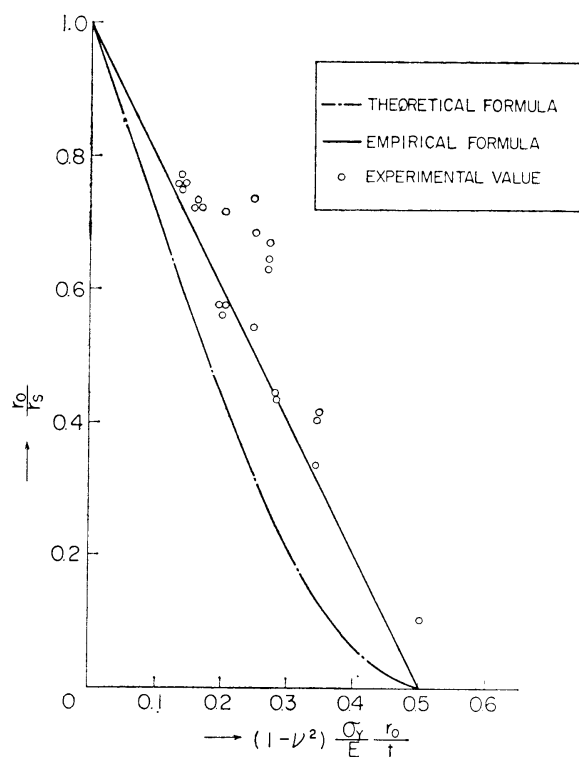

Fig. 34 シリンダー曲げ

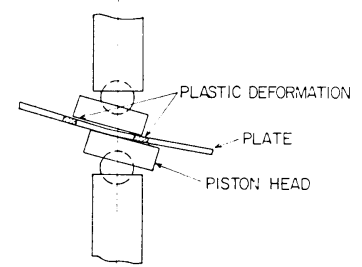

Fig. 35 ニニベーサル多点プレスの曲げ機構
弾塑性境界

$$
\zeta=\frac{\sigma_{Y}\left(1-\nu^{2}\right)}{E} r_{0}
$$

ここで， $\sigma_{Y}$ は降伏応力， $E$ はヤング率，レはポアソン比で ある。

板の曲げモーメント $M$ は

$$
\begin{array}{rl}
M=2 & b\left\{\int_{0}^{\zeta} \sigma \cdot y \cdot d y+\int_{\zeta}^{t / 2} \sigma_{Y} \cdot y \cdot d y\right\} \\
= & \frac{1}{4} \sigma_{Y} \cdot b \cdot t^{2} \cdot\left\{1-\frac{4}{3}\left(\sigma_{Y} \frac{1-\nu^{2}}{E} \frac{r_{0}}{t}\right)^{2}\right\}
\end{array}
$$

板はプレス後スプリングバックして曲率半径 $r_{s}$ になるが, この時解放されるモーメントは

$$
M=\frac{E t^{3}}{12\left(1-\nu^{2}\right)}\left(\frac{1}{r_{0}}-\frac{1}{r_{s}}\right)
$$

(14)，(15）式から

$$
\frac{r_{0}}{r_{s}}=1-3\left(1-\nu^{2}\right) \frac{\sigma_{Y}}{E} \frac{r_{0}}{t}\left\{1-\frac{4}{3}\left[\left(1-\nu^{2}\right) \frac{\sigma_{Y}}{E} \frac{r_{0}}{t}\right]^{2}\right\}
$$

上式から明らかなよらに，曲げ半経 $r_{0}$ とスプリングバック 後の曲率半経 $r_{s}$ との関係は $\left(1-\nu^{2}\right) \sigma_{Y} r_{0} / t E$ なるパラメーター によって支配される。これを図示すれば，Fig.34の一点鎖線 になる。同図で横軸が 0.5 以上は板内に塑性変形が生じること なく，荷重を取り去ると元の状態に復することを意味する。

（2）理論值と実験値の比較括よび実験式

上述の理論の妥当性を検討するために, 前章で述べたシリン ダー曲げに関する実験結果を $r_{0} / r_{s} \sim\left(1-\nu^{2}\right) \sigma_{Y} r_{0} / t E$ の形に整 理して Fig. 34 に示す。同図では, 実験值は一般に理論值より も高目になって拈り，予想されるよりもスプリングバック量が 少ないことを示している。この原因の 1 つはユニバーサル多点 プレスによって曲げられた場合, 巨視的には曲面のフェアネス は良好であるが，微視的には全体が均一に曲げられず, Fig.35 に示すようにピストンヘッドの端部近傍に塑性変形が集中し, これによって均一に曲げられたとして導いた理論値よりもスプ リングバック量が少なくなるものと思われる。 
この影鳘を敛密に考虑して曲げ加工理論を展開する事は非常に困難である。そこで，フレス後の曲面形状を支 配するパラメーターは理論的に求め, その俰数は実験結果を参考にして決定し, 実験式を作成する事にする。Fig. 34 に示した実検值に注目すると、これらはほぽ1つの直線で近似する事ができる。この直線を実線で表わし，

$$
\frac{r_{0}}{r_{s}}=1-2\left(1-\nu^{2}\right) \frac{\sigma_{Y}}{E} \frac{r_{0}}{t}
$$

とする。すなわち、シリンダー型の曲げによるスプリングパックの実験式として(17)式を採用することにする。

6.2 トーナツ 型

船体外板に現われるドーナッ型とはシリンダー型に比較的小さい縦曲率をつけたすのである。

（1）仮定および解析手順

ドーナツ型曲面（ドーナツ外型および内型）では綎曲りと横曲り のスブリングハッックが相互に影辢し合い, 縦横の曲率が近い程, こ

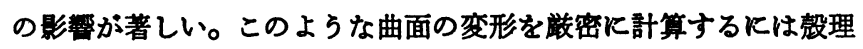
論によらねばならず, 解析的に求めることは非常に頋雑であり不可 能飞近い。そこで，実船の外板の曲率分布の㑯向を考虑し，横曲率 に比へて絽曲率は十分小さいとして、はり理論の組合わせにより， Fig. 36 に示す仮定と手順で解析する。すなわち

（a）まず，設定されたドーナッ型 $R_{0}, r_{0}$ に曲げる。その時, 横 曲りについては板の面外曲げとなり, 塑性域は Fig.33 のように板 厚の両側に生じる。縦曲りとついては断面が Fig. 37 と亦すよらな 円弧のはりと考光，応力ははりとしての曲げ応力すなわち膜応力と し，塑性域は板端に現われると考える。

（b）次に，横曲率性束されたまま縦曲りのみがはりとしてス プリングハッックし $R_{s 0}$ Kるとるるのとする。この時縦方向に膜応力 が残留応力として残る。

（c）次に，横曲率の拘束を取ると $r_{0}$ がスブリングバックして $r_{s}$ になる。この時の変化は板面外の曲げであるから,これに要する 力は比較的小さく, 縱方向の膜応力は楨曲率がスブリングハッックす る間変化しないと考光るのが妥当である。従って， $r_{0} か ゙ r_{s}$ となる 間, 縦方向は板面外の曲げだけが横方向と平衡するまで变化する。

\begin{tabular}{|c|c|c|c|}
\hline & (1) & (2) & (3) \\
\hline 傈曲り & Ro & Rso & $R_{s}$ \\
\hline 榃曲り & $r_{0}$ & $r_{0}$ & $r_{s}$ \\
\hline 条件 & $\begin{array}{l}\text { Ro, rok } \\
\text { 曲 I゙3 }\end{array}$ & 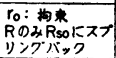 & 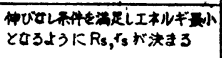 \\
\hline
\end{tabular}
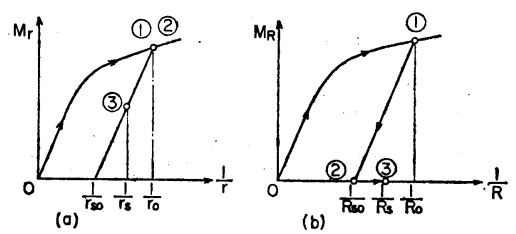

Fig. 36 ドーナッ型の变形

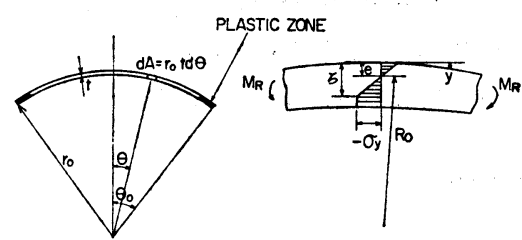

(a)

(b)

(2) 縦曲け゚とスプリングハッック

(a) 弾塑性曲げ

モーメント $M_{R}$ で均一飞曲げられた時の縦応力分布は，Fig.37 に示すように板端の部分たけと塑性変形が生 しると仮定する。そしてモーメント $M_{R}$ を取り除いた時, 横方向の曲率半経 $r_{0}$ は変化しないで縦方向のみス プリングバックするすのとする (Fig.36 (1)〜(2)。

坐標 $y$ および弾望性境界までの距離 6 は

$$
\left.\begin{array}{l}
y=r_{0}(1-\cos \theta) \\
\zeta=r_{0}\left(1-\cos \theta_{\zeta}\right)
\end{array}\right\}
$$

応力分布は眓から次のように仮定する。

$$
\left.\begin{array}{ll}
\sigma=a+b y=a+b r_{0}(1-\cos \theta) & \left(0 \leq \theta \leq \theta_{\zeta}\right) \\
\sigma=-\sigma_{Y} & \left(\theta_{\zeta} \leq \theta \leq \theta_{0}\right)
\end{array}\right\}
$$

$\theta=\theta_{\zeta}$ で $\sigma=-\sigma_{Y}$ および軸方向の合力が零である事から

中立軸を $y=e$ とすれば

$$
\left.\begin{array}{l}
a=-\sigma_{Y}-\frac{\sigma_{Y} \theta_{0}\left(1-\cos \theta_{\zeta}\right)}{\theta_{\zeta} \cos \theta_{\zeta}-\sin \theta_{\zeta}} \\
b r_{0}=\frac{\sigma_{Y} \theta_{0}}{\theta_{\zeta} \cos \theta_{\zeta}-\sin \theta_{\zeta}}
\end{array}\right\}
$$

$$
e=-\frac{a}{b}=\frac{r_{0}}{\theta_{0}}\left\{\theta_{\zeta} \cos \theta_{\zeta}-\sin \theta_{\zeta}+\theta_{0}\left(1-\cos \theta_{\zeta}\right)\right\}
$$


また $y=\zeta$ で $\varepsilon=-\sigma_{Y} / E=-\varepsilon_{Y}$ であるから

$$
(\zeta-e) / R_{0}=\varepsilon_{Y}
$$

(18)，(21)，(22）式より次式を得る。

$$
-\frac{r_{0}}{R_{0} \theta_{0}}\left(\theta_{\zeta} \cos \theta_{\zeta}-\sin \theta_{\zeta}\right)=\varepsilon_{Y}=\frac{\sigma_{Y}}{E}
$$

$\theta$ は一般に小さいので高次の項を省略し， $\theta_{0}=b / 2 r_{0}$ を上式に代入すると

$$
\frac{\theta_{\zeta}}{\theta_{0}}=\sqrt[3]{\frac{12 \varepsilon_{Y} R_{0} r_{0}}{b^{2}}}=\sqrt[3]{\frac{12 \sigma_{Y} R_{0} r_{0}}{E b^{2}}}
$$

また（23）式を用いて（20）式を表わすと

となり，曲げモーメントは

$$
\left.\begin{array}{l}
a=-\sigma_{Y}+E r_{0}\left(1-\cos \theta_{\zeta}\right) / R_{0} \\
b=-E / R_{0}
\end{array}\right\}
$$

$$
\begin{aligned}
M & =-2\left\{\int_{0}^{\theta_{\zeta}} \sigma \cdot y \cdot d A-\int_{\theta_{\zeta}}^{\theta_{0}} \sigma_{Y} \cdot y \cdot d A\right\} \\
& =-2\left\{\int_{0}^{\theta_{\zeta}}\left[-\sigma_{Y}-E \frac{r_{0}}{R_{0}}\left(\cos \theta_{\zeta}-\cos \theta\right)\right] r_{0}^{2} t(1-\cos \theta) d \theta-\sigma_{Y} \int_{\theta_{\zeta}}^{\theta_{0}} r_{0}^{2} t(1-\cos \theta) d \theta\right\}
\end{aligned}
$$

となる。これより

$$
\begin{aligned}
M_{R}=E\left(\frac{r_{0}}{R_{0}}\right) r_{0}^{2} t \theta_{\zeta}\left\{1-\frac{\sin 2 \theta_{\zeta}}{2 \theta_{\zeta}}+2\right. & \left.\left(\cos \theta_{\zeta}-\frac{\sin \theta_{\zeta}}{\theta_{\zeta}}\right) \frac{\sin \theta_{0}}{\theta_{0}}\right\} \\
= & \frac{E}{45}\left(\frac{r_{0}}{R_{0}}\right) r_{0}^{2} t \theta_{\zeta}{ }^{3}\left(5 \theta_{0}^{2}-3 \theta_{\zeta}^{2}\right)
\end{aligned}
$$

（b）スプリングバック

横曲り $r_{0}$ を拘束したまま，加光た縦曲げモーメント $M_{R}$ を除去すると、はりとしてのスプリングバックが生 し，この時に開放されるモーメントは（26）式と大きさが等しい弾性モーメントであるとする。スプリングバッ ク後の曲率半経を $R_{s 0}$ とすれば

ここで

$$
M / E I=1 / R_{0}-1 / R_{s 0}
$$

$$
I=r_{0}^{3} t \theta_{0}\left\{1+\frac{\sin 2 \theta_{0}}{2 \theta_{0}}-\frac{2 \sin ^{2} \theta_{0}}{\theta_{0}^{2}}\right\}
$$

である。従って（27）式は

$$
M=E\left(\frac{1}{R_{0}}-\frac{1}{R_{s 0}}\right) r_{0}{ }^{3} t \theta_{0}\left\{1+\frac{\sin 2 \theta_{0}}{2 \theta_{0}}-\frac{2 \sin ^{2} \theta_{0}}{\theta_{0}{ }^{2}}\right\} \div \frac{2}{45} E\left(\frac{1}{R_{0}}-\frac{1}{R_{s 0}}\right) r_{0}^{3} t \theta_{0}^{5}
$$

(26)，(28）式より

$$
\frac{R_{0}}{R_{s 0}}=1-\frac{5}{2}\left(\frac{12 \sigma_{Y}}{E} \frac{R_{0} r_{0}}{b^{2}}\right)\left\{1-\frac{3}{5}\left(\frac{12 \sigma_{Y}}{E} \frac{R_{0} r_{0}}{b^{2}}\right)^{2 / 3}\right\}
$$

上式より，横変形を拘束した場合の縦曲率のスプリングバックは $12 \sigma_{Y} R_{0} r_{0} / b^{2} E$ なるパラメーターに支配され ることがわかる。上式はかなり複雑な式だから，これを2 次曲線で近似し，

$$
\frac{R_{0}}{R_{s 0}}=\left(1-12 \frac{\sigma_{Y}}{E} \frac{R_{0} r_{0}}{b^{2}}\right)^{2}
$$

スプリングバックを整理するために上式を用いることにする。

（3）横曲りと糈曲りのスプリングバック（相互干渉）

(a) 伸びなし条件

Fig. 36 で(2)の状態から(3)の状態へ移行する場合を考劣る。(2)の状態では膜応力の残留応力が緃方向に平衡し， 曲率半経が $R_{s 0}$ となるように膜歪が残っている。(3の状態へ移行する際, 主として横曲率がスプリングバックを 起こし, 緃方向の膜ひずみは変化しないまま, 板の面外曲げだけが生じて平衡状態に落ちつくものと考兄られる。 膜ひずみは断面が中立軸に対して対称ではないから，戦密に計算するのはかなり複雑であるが，ここでは近似 的に縦曲率半経 $R_{s 0}$ になった時の弾性ひずみで代用する。

曲率半経 $R_{50}$, 断面の半経 $r_{0}$ の時の弾性ひずみは次の形に仮定する。

$$
\varepsilon=a+b y=a+b r_{0}(1-\cos \theta)
$$


$y=0(\theta=0)$ で $\varepsilon=e / R_{s 0}, y=e$ で $\varepsilon=0$ と軸力なしの条件から $a, b, e$ を決定すれば

$$
\varepsilon=\frac{r_{0}}{R_{s 0}}\left(\cos \theta-\frac{\sin \theta_{0}}{\theta_{0}}\right)=\frac{b^{2}}{24 R_{s 0} r_{0}}\left\{1-12\left(\frac{s}{b}\right)^{2}\right\}
$$

ここに, $\theta_{0}=b / 2 r_{0}, \theta=s / r_{0}, s$ は $\theta=0$ から測ったガースに沿った距離である。

上式のひず文が変化せずに $R_{s 0} \rightarrow R_{S}, r_{0} \rightarrow r_{s}$, すなわち(3)の状態に移行するためには

$$
R_{s 0} r_{0}=R_{s} r_{s}
$$

が成立しなければならない。これが伸びなし条件である。

(b) スプリングパック

横曲率が（32）式の条件を満足しながらスプリングバックを起こし, 横曲りと縦方向の板の面外曲げの力が釣 り合った状態で安定する力の平衡条件の代わりに, ここではエネルギー条件を用いる。

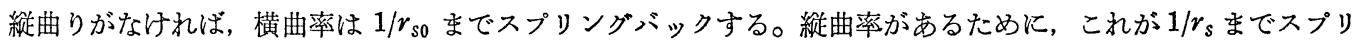
ングバックしたとすれば, 横曲げが保有しているひずみエネルギーは Fig.36 (a) の斜線部分の面積で表わされ,

$$
V_{r}=\frac{1}{2} b M\left(\frac{1}{r_{s}}-\frac{1}{r_{s 0}}\right)=\frac{1}{2} D b\left(\frac{1}{r_{s}}-\frac{1}{r_{s 0}}\right)^{2}
$$

ここで

$$
D=\frac{E t^{3}}{12\left(1-\nu^{2}\right)}
$$

縦曲げについては曲率半経 $R_{0}$ は大きく，これによって縦方向の板面外の塑性変形は起こらないと仮定する と, 断面半経 $r_{s}$ の板が曲率 $1 / R_{S}$ まで变形する時に貯えられるひずみエネルギーは

$$
V_{R}=\frac{1}{2} \times 2 \int_{0}^{\theta_{0}} D K_{s}^{2} r_{s} d \theta=\frac{1}{2} D \frac{r_{s}}{R_{s}^{2}} \theta_{0}\left\{1+\frac{\sin 2 \theta_{0}}{2}\right\}
$$

ここで

$$
K_{s}=\frac{1}{R_{s}} \cos \theta
$$

全ひずみエネルギーは

$$
V=\frac{1}{2} D b\left\{\left(\frac{1}{r_{s}}-\frac{1}{r_{s 0}}\right)^{2}+\frac{1}{R_{s}^{2}}\left[1-\frac{1}{12}\left(\frac{b}{r_{s}}\right)^{2}\right]\right\}
$$

全ひずみエネルギーを（32）式の条件のあとで最小にすると次式を得る。

$$
\left(\frac{r_{0}}{r_{s}}\right)^{3}\left(\frac{r_{0}}{r_{s}}-\frac{r_{0}}{r_{s 0}}\right)-\left(\frac{R_{0}}{R_{s 0}}\right)^{2}\left(\frac{r_{0}}{R_{0}}\right)^{2}=0
$$

上式で板の寸法拉よび $\sigma_{Y}, R_{0}, r_{0}$ などが与えられると $r_{0} / r_{s 0}$ はシリンダーのスプリングバックであるから (17) 式より計算できる。また， $R_{0} / R_{s 0}$ は $(30)$ 式から求めら れる。したがって，(36）式は $r_{0} / r_{s}$ に関する 4 次方程式 となり，その正の実根が求める $r_{0} / r_{s}$ である。 $r_{0} / r_{s}$ が求 まると $R_{0} / R_{s}$ は (32) 式执よび (30) 式から計算でき る。

\section{（4）理論と実験結果の比較}

理論解と実験結果を比較するために（32）式を変形す ると

$$
\sqrt{\frac{r_{0}}{r_{s}} \frac{R_{0}}{R_{s}}}=\sqrt{\frac{R_{0}}{R_{s 0}}}=1-\frac{12 \sigma_{Y}}{E} \frac{R_{0} r_{0}}{b^{2}}
$$

つぎに，実験結果から $\sqrt{r_{0} R_{0} / r_{S} R_{S}}$ を求め, $12 \sigma_{Y} R_{0} r_{0} /$ $E b^{2}$ に対しプロットすれば Fig. 38 のごとくなり，ほと んどの実験点は直線（37）式のまわりに集って扣り, 縦 曲率と横曲率のスプリングハックの干渉は（37）式で表 わすことができる。

つぎに，横曲率のスプリングバックを考える。(36)式

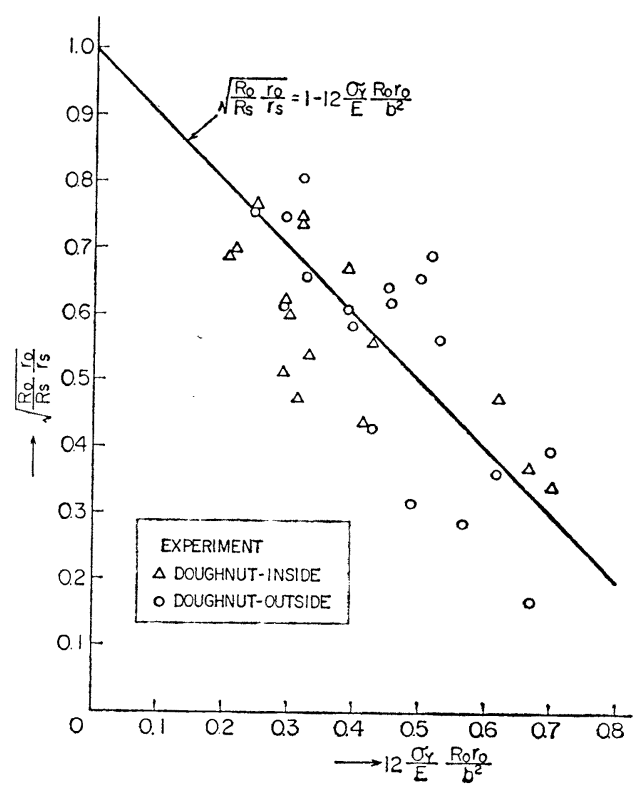

Fig.38 ドーナツ型の曲げ加工 


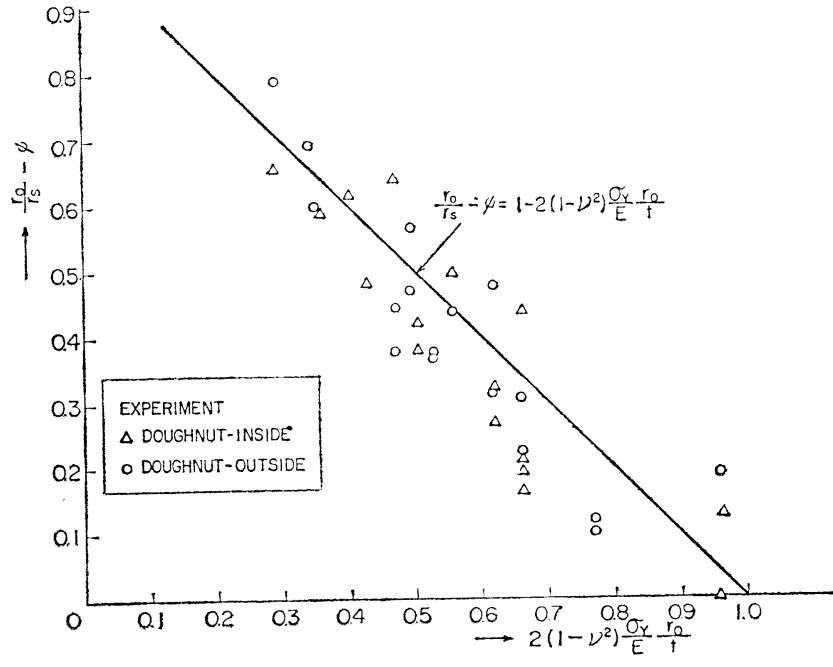

Fig.39 ドーナツ型の曲げ加工

ナッ型の横曲りの実験式として採用することにする。

$$
\frac{r_{0}}{r_{s}}-\varphi=1-2\left(1-\nu^{2}\right) \frac{\sigma_{Y}}{E} \frac{r_{0}}{t}
$$

な特，縦曲りは（37）式と（39）式より求めることができる。

\section{3 球 型}

球面の曲げの解析には殼理諭を用いる必要があり，かなりあらい近似解であっても解析解は複雑な形になると 考えられる。一方，実際の船体外板で球面の現われるのはごくまれである。そこで，本節では詳しい理論解析を 行わず，力学的考察と実験值の傾向から，種々のパラメーターを設定し，これによって実験值を整理して，実験 結果を表現し得るパラメーターを検討する。

平板が球面に加工される場合，第 1 近似として，変形によるひずみエネルギーの大部分は膜応力によるもので あると考えると，スプリングパックを支配するパラメ 一ターは板厚に無関係となり， $\sigma_{Y}\left(R_{0} / b\right)^{n} / E$ で表わさ れる。そこで定数 $n$ を変えて実験結果を整理すると， 非常にばらつき，このパラメーターだけを用いて整理 できないことが明らかになった。

実験結果によると $R_{0} / R_{s}$ には板厚が直接的に影響を 及ぼしているので，上記パラメーターとシリンダー曲 面のパラメーターを折孛した形を考えて， $\sigma_{Y} R_{0}{ }^{2} / E b t$ なるパラメーターで整理して Fig. 40 に示す。図によ れば実験值の大部分は 1 つの直線に近づいてる。そ こで, この直線を球型曲げの実験式として用いること にする。

$$
\frac{R_{0}}{R_{S}}=1-\frac{3}{26} \frac{\sigma_{Y}}{E} \frac{R_{0}^{2}}{b t}
$$

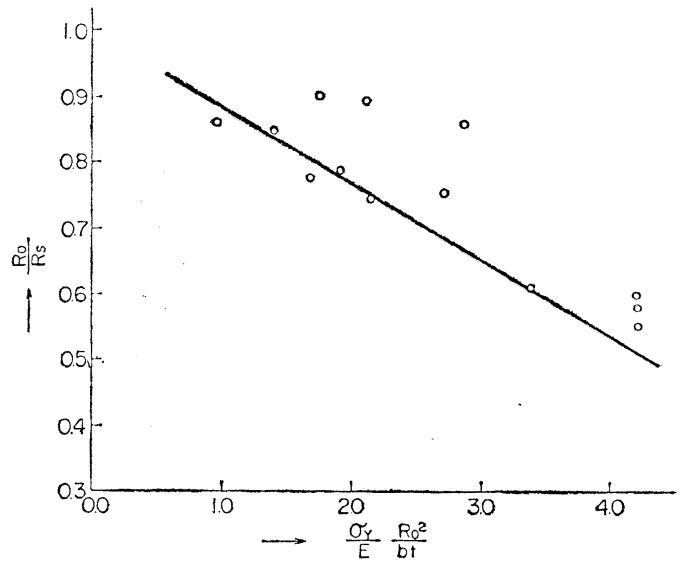

Fig. 40 球型の曲 ゙゙加工

\section{7 結論}

船体外板の曲げ作業を自動化するための基礎的な研究を行った結果以下の事柄が明らかになった。

（1）船体外板の曲げ作業を自動化するための加工法としてはプレス方式が最も適しているものと思われる。

（2）曲げ加工の対象となる船体外板は極めて浅い曲がり形状をしている。すなわち，板長さ方向の曲率は極 めて小さく，その $95 \%$ が $0.02 \mathrm{~m}^{-1}$ 以下で，板幅方向の曲率は $95 \%$ が $0.2 \mathrm{~m}^{-1}$ 以下であり，縦横両曲率半 
経の比は相当大きい。

（3）小形単一曲げ型による曲げ加工実験の結果は, 成型結果の再現性拉よび成型曲面のフェアネスは良好で あった。プレス荷重として押し切りの必要はなく, また加熱曲げはメリットが少ない。

（4）単一曲げ型に円板型ワッペンを貼布した実験結果はワッペンなしの場合と同㥞良好であるが, ワッペン のピッチを大きくすると薄板では座屈が発生した。

ユニバーサル多点プレスの実用機で座屈が発生しないためには, 多点ピストンのピッチを $250 \mathrm{~mm}$ 程度に押え る必要がある。

（5）ニニバーサル多点プレス装置による大形実験の結果から次のことがわかった。

(a) 再現性特よび曲面のフェアネスは良好である。

（b）ピストンピッチが $141 \mathrm{~mm}$ の場合はもちろん，200 mm の場合にもフェアネスは良好であり，座屈は生 しなかった。

（c）プレス後のスプリングバック量は試験片の板厚に反比例し設定曲率半径比比例して大きくなる。

（d）ラップ押しをしても成型曲面のフェアネスは良好である。

（e）加圧順序が成型結果に影響を及ぼす。従って実用機では多点ピストンを板幅方向にブロック分けし，中 心部のブロックから順番にプレスして行くのが良い。

（6）プレス後の仕上り曲面形状を支配するパラメーターを理論的に求めてシリンダー型，ドーナシ型および 球型のスプリングバックの実験式を作成した。すなわち

(a) シリンダー型曲げに対しては, 曲げ変形を考慮してパラメーターを選び実験式として(17)式を作成した。

（b）ドーナッ型曲げに対しては縦曲りと横曲りの相互影響を考虑してパラメーターを選び実験式として(39) 式を作成した。

（c）球型曲げに対しては，曲げ応力の他に膜応力を考慮してパラメーターを選び, 実験式として（40）式を 作成した。

（7）以上の結果から, 船体外板曲げ作業にニニバーサル多点プレス方式を実用化する事は可能であるとの結 論を得た。

引続き第 2 報では土ニバーサル多点プレス方式による板曲げ加工の自動化の一案について行った研究結果を述 ベる予定である。

な颃最後に本研究は日本造船研究協会第 110 研究部会の研究の一環として行われたものである事を付して感謝 の意を表します。

\section{参 考 文 献}

1) 北野広雄: 鋼板曲げ加工用万能調整式プレス機械の研究, 京都大学学位論文, (昭和 36 年 1 月).

2) P. G. Hodge, Jr. : Plastic Analysis of Structures, McGraw-Hill, (1959). 